\title{
CULTO A LOS ANCESTROS EN ÉPOCA ROMANA: LOS CIPOS FUNERARIOS DE LAS NECRÓPOLIS DE BAELO CLAUDIA (BOLONIA, CÁDIZ)
}

\author{
ALICIA JIMÉNEZ DÍEZ ${ }^{1}$ \\ Instituto de Historia, CSIC
}

\section{RESUMEN}

Se han publicado propuestas muy diversas para explicar la función de un singular conjunto de piezas (bautizadas como "muñecos" a principios del siglo XX) que se hallaron asociadas a distintos enterramientos de las necrópolis de Baelo Claudia. En el presente estudio se propone entender los cipos funerarios de Bolonia dentro de un contexto ritual más amplio que permite relacionarlos con el culto a los ancestros (concebidos y representados como una comunidad de carácter indiferenciado), no sólo en la tumba, sino también en ambientes domésticos y en santuarios.

\section{ABSTRACT}

A quite large number of proposals have been published about the meaning of a singular group of pieces (termed 'dolls' at the beginning of the twentieth century) found in association with different tombs in the necropoleis of Baelo Claudia. In this paper I suggest we can only understand the funerary cippi of Bolonia within a wider ritual context that places these sculptures in relation with cult to ancestors (that are seen and represented as a community where individuals can not be differentiated) not only in the tomb, but also in domestic and sanctuary contexts.

PALABRAS CLAVE: Baelo Claudia. Cultos funerarios. Cipos liminales. Imagines. Simulacra. Dobles. Objetos arcaizantes. Época romana. Mediterráneo occidental.

KEY WORDS: Baelo Claudia. Funerary cults. Liminal cippi. Imagines. Simulacra. Doubles. 'Archaic' materials. Roman times. Western Mediterranean.

\footnotetext{
1 Contrato Postdoctoral I3P financiado por el Fondo Social Europeo. Proyecto de Investigación SP6.E.58/03.

2 Muchas de las nuevas ideas que aquí se presentan surgieron como consecuencia de una serie de conversaciones con el Prof. Michael Rowlands que tuvieron lugar en el Departamento de Antropología de University College London entre finales de 2004 y principios de 2005 , que quedaron ya en parte reflejadas en mi Tesis Doctoral. Quiero agradecer también los comentarios y sugerencias realizadas por M. Bendala Galán (Universidad Autónoma de Madrid), P. van Dommelen (University of Glasgow), M. P. García-Bellido (CSIC), G. López Monteagudo (CSIC), I. Seco Serra (Cuerpo Facultativo de Conservadores de Museos) y dos informantes anónimos del Archivo Español de Arqueología, así como la ayuda de J. R. Carrillo Díaz-Pinés (Universidad Pablo de Olavide).
}

\section{LA CIUDAD DE BAELO CLAUDIA ${ }^{2}$}

Belo Claudia, situada junto al Estrecho de Gibraltar, frente a las costas de Tánger, es un ejemplo especialmente interesante para el estudio de los fenómenos de hibridismo que se pueden asociar al contacto colonial entre población local y romana en el sur de la península ibérica. Fundada a finales del siglo II a. C., sobre un solar aparentemente virgen, permite observar aún en la actualidad algunos de los elementos más característicos de una ciudad romana, como un trazado viario ortogonal, el foro, diversos templos, el macellum, la basílica, las termas, el teatro o los acueductos (fig. 1). Sin embargo, no debe olvidarse que la gran mayoría de estos elementos deben situarse en un momento avanzado de la historia del asentamiento, ya en época claudia; y que, posiblemente, la ciudad no recibe el estatuto de municipio latino hasta este momento. Las necrópolis asociadas pueden considerarse, grosso modo, contemporáneas del resurgir edilicio de Belo, y, sin embargo, presentan ciertos elementos que pueden relacionarse con determinados aspectos de tradición púnica, como las famosas 'estelas betiliformes' estudiadas en el presente artículo. Gracias a la iconografía y a las leyendas neopúnicas encontradas en las monedas de época republicana de Bailo sabemos también que la ciudad se encontraba en este período bajo un gobierno púnico, que acuña siguiendo fórmulas administrativas, patrones metrológicos y elementos iconográficos que remiten al norte de África y donde los indicios de contactos con el mundo latino son aún escasos (García-Bellido, 2001: 326; García-Bellido, Blázquez, 2001: 51). Lo mismo sucede con el propio nombre de la ciudad, que podría remitir a un topónimo de tipo púnico.

El objetivo de estas páginas es proponer una nueva interpretación de los cipos encontrados en las necrópolis de Bolonia, basándose en sus particularidades rituales, que permiten analizarlos como un fenómeno específico de esta ciudad gaditana e insertarlos en un debate más amplio sobre el culto a los ancestros en época romana, donde el recurso a elementos arcaizantes esencialmente híbridos -como las piezas que aquí se estudian- debe considerarse un fenómeno característico de 


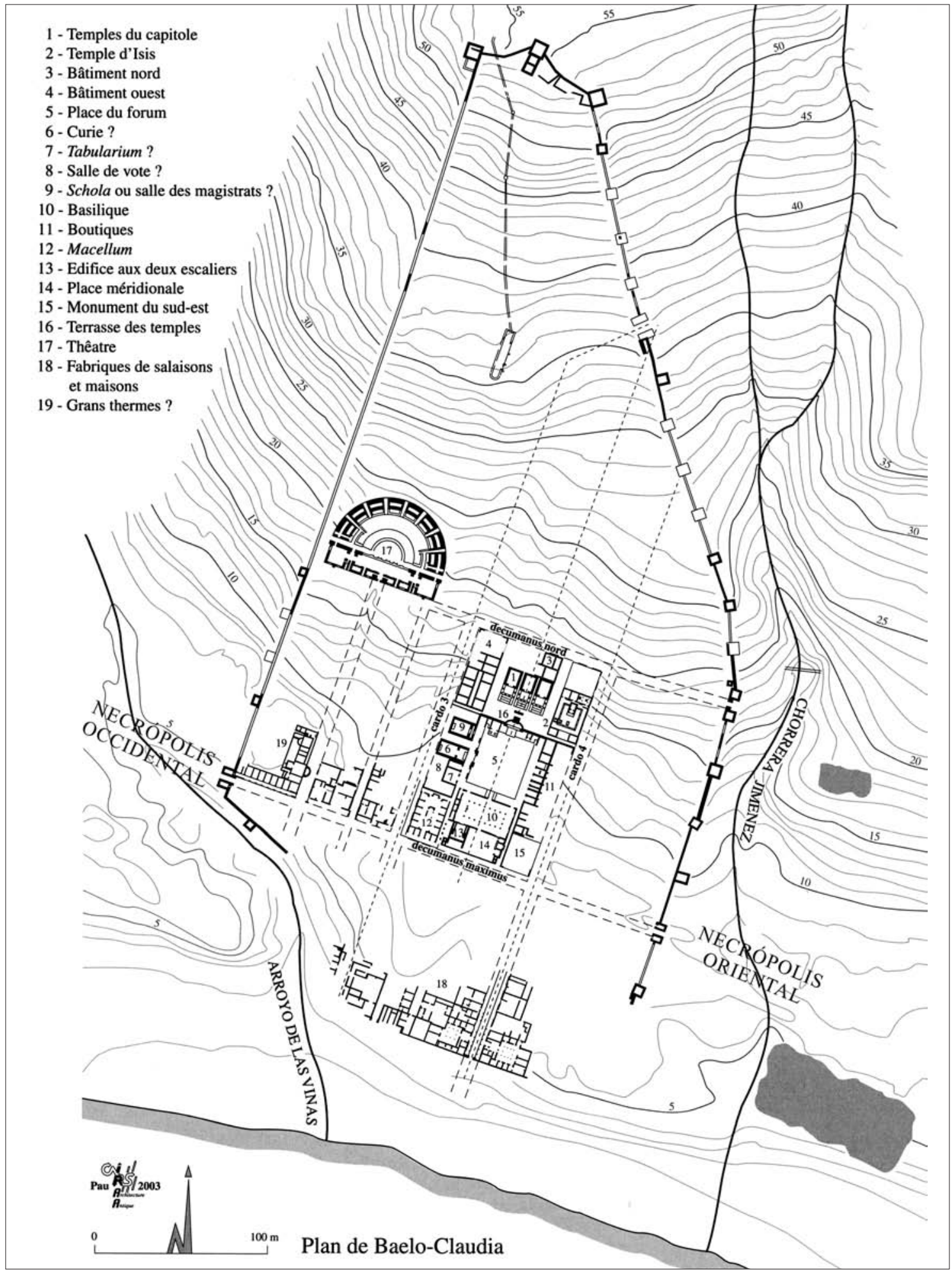

Figura 1. Baelo Claudia. Plano general del yacimiento con la ubicación de las necrópolis principales de época altoimperial (modificado a partir de la fig. 1 de Ney; Paillet, 2006). 
situaciones coloniales como las que dieron forma al Imperio Romano.

Aunque Baelo Claudia es uno de los núcleos romanos más antiguos de la Península, apenas se conocen datos sobre los primeros 100 años de vida del asentamiento $^{3}$. Lo que sí parece claro es la fundación de la ciudad sobre un solar virgen hacia finales del s. II a. C., ya que hasta el momento no se han encontrado en el yacimiento fragmentos de cerámica tartésica, fenicia o griega. Hace años se sugirió la posible relación de Belo con un asentamiento de época prerromana situado en la cumbre más elevada de la vecina Sierra de la Plata, conocida como "La Silla del Papa", en la que ya P. Paris había señalado la existencia de restos arqueológicos (Domergue, 1973: 102-103). En dicho lugar se ha podido documentar un oppidum de "aspecto típicamente ibérico" (Sillières, 1997: 70), que contaba con una serie de viviendas semi-talladas en la roca así como con una muralla y que ocupaba una

3 Las primeras excavaciones en Baelo Claudia, que pusieron al descubierto algunas cubetas de salazones, fueron llevadas a cabo por un capitán de aduanas llamado Félix González, allá por el año 1870. Casi cuatro décadas después, en 1907, el padre Julio Furgús 'excavó' en sólo cuatro días unas cuarenta tumbas (Furgús, 1907, Id., 1908). En 1914, Pierre Paris se detiene en Bolonia y deja constancia de su visita al yacimiento en un artículo que verá la luz en plena primera guerra mundial (Paris, 1917). Precisamente en este momento comenzarán las intervenciones arqueológicas de su equipo en las necrópolis (Bonsor, Mergelina) que se prolongarán hasta 1921. Habrá que esperar más de cuarenta años para que las intervenciones arqueológicas se reanuden a cargo de la Casa de Velázquez de Madrid, que llevará a cabo veinticuatro campañas de excavación entre 1966 y 1990, entre las que se incluyen las realizadas por J. Remesal en la necrópolis SE. Poco antes, durante el verano de 1989, el yacimiento pasa a ser considerado "Conjunto Arqueológico" por la Junta de Andalucía, iniciándose toda una serie de intervenciones encaminadas a la protección de los restos arqueológicos (expropiación de terrenos, restauración, creación de caminos con sistemas de drenaje, etc.) y a la divulgación (Álvarez Rojas, 2002). Las excavaciones más recientes que se han realizado en el yacimiento se deben a la Universidad de Cádiz, que ha llevado a cabo una serie de cursos de verano en Bolonia, centrados, fundamentalmente en el estudio de la industria de salazones (Arévalo, Bernal, 2007). La construcción de un polémico edificio, destinado a ser el nuevo Centro de Interpretación del yacimiento, y de una serie de infraestructuras para mejorar los accesos a la ciudad antigua han puesto también al descubierto un nuevo conjunto de enterramientos de época tardoantigua. Las referencias bibliográficas más relevantes para el estudio de las necrópolis del asentamiento son las siguientes: Furgús (1907); Id., (1908); Paris et al. (1926); Mergelina (1927); Bourgeois, Amo (1970); Remesal (1979), Sillières (1997) y Jiménez Díez (e.p.a). Para una comparación entre las necrópolis de Baelo Claudia y otros lugares de enterramiento de época romana donde la perduración de elementos púnicos es patente véase Bendala (1991, 1995 y 2002). superficie aproximada de 3 hectáreas ${ }^{4}$. Sin embargo, las prospecciones realizadas hasta la fecha sobre el terreno sólo han proporcionado fragmentos de cerámica común, ánforas Dressel I, cerámica pintada ibérica y campaniense A y B que parecen situar la vida de este poblado en un momento tardío del mundo ibérico, en torno a los siglos II-I a. C. Aunque resulta difícil pronunciarse sobre la relación de este asentamiento que domina, desde lo alto, el territorio de Belo, con la ciudad romana, antes de que se realice algún tipo de excavación arqueológica, resulta al menos interesante constatar, que, al igual que en otros casos paradigmáticos del sur peninsular, como por ejemplo Corduba, el núcleo indígena convive, posiblemente durante al menos un siglo, con su supuesto sucesor de época imperial.

Parece pues que el asentamiento situado junto a la costa que ostentará, por cierto, como tantas otras ciudades, un nombre de origen no romano, Baelo, puede remontarse a un momento indeterminado de finales del s. II a. C. como ha podido constatarse en diversos sondeos ${ }^{5}$. Desde los primeros momentos el asentamiento acuñará moneda. Es precisamente en estas primeras amonedaciones bilingües, con leyendas en un neopúnico aberrante y en las que se recurre a elementos icono-

4 P. Sillières (1997: 70) se hace eco de la identificación por parte de A. Schulten (F.H.A. IV: 170) de La Silla del Papa con el Mons Belleia citado por Salustio (Historias, 1, 105). Sabemos que en dicho lugar se instalaron los lusitanos de Sertorio en el 80 a. C. P. Sillières sugiere, por tanto, una posible relación entre el abandono del asentamiento prerromano a lo largo del siglo I a. C. con algún tipo de represalia por su apoyo al bando sertoriano. De ser así, la decadencia de los últimos años de la ciudad 'indígena' podría explicarse quizá por la imposición por parte de Roma de un reasentamiento de la población en el llano, junto al mar, en lo que sería más tarde la ciudad romana. Sin embargo, esta hipótesis no permite explicar la fundación de la ciudad romana junto al núcleo 'indígena' a finales del siglo II a. C., es decir, en un momento anterior a las guerras sertorianas y el tipo de relación que existió entre ambas en la primera etapa de ocupación del lugar.

5 En la parte suroeste del yacimiento, no lejos del decumano máximo (sondeos 26, 29 y 40 de 1966), bajo el macellum (sondeo 11, 12, 15 y 17) y bajo la factoría de salazones vecina a este último (Domergue 1973: 66-76, 39-49, 59-66; Didierjean et al. 1986: 80-84, 89; Dardaine, Bonneville, 1980: 403-408; Sillières, 1997:52). En el sondeo $\mathrm{S} 7$ realizado en la factoría de salazones se encontró una moneda de Ebusus de la primera época (300-214 a. C.) aunque otros materiales del mismo sondeo -no sabemos si del mismo estrato- se fechan en el s. I a. C. Éste y otros indicios, según S. Dardaine y J. -N. Bonneville (1980: 406) “confirme donc la présence d'un habitat dense à partir du milieu du Ier siècle avant J. C. Mais les témoins antérieurs son suffisamment nombreux pour attester l'existence de relations commerciales, suivies et lointaines, pendant le IIe siècle avant J. C.". 
gráficos característicos del ámbito púnico (GarcíaBellido 1985-1986, 1993), donde se recoge el nombre que la ciudad mantendrá a lo largo de su historia ${ }^{6}$. Desgraciadamente, sólo sabemos de la existencia de cinco estructuras que puedan remontarse a este período -dos cubetas de salazones (fines s. II a. C.-principios s. I a. C.), dos muros y una canalización en terracota-, pero se puede afirmar que desde el comienzo la ciudad contó con una fábrica de salazones, y poco después, ya en el siglo I a. C., con dos talleres de cerámica (oficinas de M. Lucretius, L. Caes(...) y de C.Avienus) que producían ánforas (Dressel 1C y 21/22), tejas y ladrillos (Cf. ahora Arévalo, Bernal, 2007).

Los restos de época augustea son mucho más abundantes y se han recuperado en prácticamente todos los cortes arqueológicos que se han realizado en el yacimiento. En este momento se produce una importante remodelación de la ciudad. Se arrasan diversas estructuras de época anterior y se construyen y planifican la mayoría de elementos que dotarán a Belo de su futuro carácter urbano, como la muralla, el trazado ortogonal de las calles y muy posiblemente el foro donde quizá se ubicó ya un santuario. Se ha querido hacer coincidir todos estos cambios, y la bonanza económica del núcleo urbano, que se podría deducir a partir del aumento del hallazgo de monedas y cerámicas importadas en los estratos de esta época, con la concesión del estatuto de municipium por parte del emperador (Sillières 1997: 29, 56; id., 2006: 50). Como argumento en apoyo de esta hipótesis puede aducirse fundamentalmente la adscripción a la tribu Galeria de los ciudadanos de Bolonia.

Pero el verdadero apogeo de la ciudad no tuvo lugar hasta época claudia. La mayoría de las grandes construcciones que aún se conservan en el yacimiento datan de este período. Es el caso de los tres templos del foro - que muy probablemente no deban identificarse con un capitolio sino con un lugar de culto dedicado a una tríada divina de origen púnico (Bendala, e.p., García-Belli-

6 En las fuentes se la denomina Belon (Str. 3,1, 8), Bailon (Ptol. 2,4,5), Baelo (Mela 2,96; Plin. 3,7). Las primeras emisiones de moneda de la ciudad recogen una leyenda del tipo "los ciudadanos de Bailo" (b'l/'bln). En la segunda emisión aparece una fórmula púnica que también puede encontrarse en el numerario gaditano: "acuñación de...", “obra de..." (p'lt) (García-Bellido, Blázquez, 2001: 51). Para la datación de dichas amonedaciones véase: García-Bellido, Blázquez (2001: 51-52, primera mitad del s. I a. C., entre interrogaciones), Alfaro et al. (1997: 109, mitad del s. II a. C. - s. I a. C.), Villaronga (1979: 165 y 1994: 124, s. II a. C.), Solá-Solè (1980: 11, entre fines del s. II a. C. y fines del I a. C.) y Guadán (1969: 128-131, finales del s. II a. C, - principios del s. I a. C.). Sobre las monedas halladas en el yacimiento puede consultarse Bost et al. (1987); Paris et al. (1923: 34, fig. 10.1) y Paris et al. (1926: 191). do, 2001) ${ }^{7}$-, el templo de Isis, la basílica, la posible curia, el posible tabulario, el mercado o macellum, el teatro, acueductos, termas, casas y factorías de salazón más recientes. El colapso de la muralla en algunos puntos durante esta época podría ser un indicio de que la causa directa del arrasamiento de algunas estructuras augusteas y la reconstrucción del centro monumental pudo deberse, al menos parcialmente, a algún tipo de movimiento sísmico, aunque, fundamentalmente, se tiende a relacionar todas estas edificaciones con una nueva promoción de la ciudad. La concesión del estatuto de municipio de ciudadanos romanos, podría explicar, en ese caso, el término Claudia que se añade al primitivo nombre del asentamiento (Sillières 1997: 29).

A finales del siglo II d. C. comienzan a abandonarse algunas tiendas del macellum y la basílica, pero la ciudad no parece sumirse en una fase de decadencia definitiva hasta el siglo III d. C., si bien el núcleo continúa siendo habitado. En la segunda mitad del s. IV d. C. el registro arqueológico señala de nuevo cierta concentración de habitantes en Belo. Puede decirse que la ciudad no se convertirá en un despoblado hasta el siglo VII d. C. (Sillières 1997: 62-63).

\section{LAS NECRÓPOLIS DE BAELO CLAUDIA: CULTO A LOS ANCESTROS EN LA TUMBA}

Prácticamente desde los primeros trabajos en el yacimiento se pudo definir la existencia de dos zonas de enterramiento principales: la necrópolis occidental, situada junto a la vía de Gades, y la necrópolis oriental, que se extendía a ambos lados de la calzada que se dirigía hacia Carteia. A este área funeraria pertenecen tam-

\footnotetext{
7 M. Bendala ha argumentado que las tres edificaciones no responden a la estructura canónica de los capitolios romanos. No se trata de un templo tripartito, con un pórtico común, sino de tres edificios independientes, donde además, el que ocupa el lugar central, que debería haber sido destinado a la imagen de Iupiter, es de menor tamaño. La modulación de estos templos o las esculturas halladas en su interior son otras evidencias que refuerzan la hipótesis de una interpretatio romana de cultos dedicados a una tríada divina de carácter púnico, vinculada quizá, en este espacio sacro, a la imagen del emperador como genius civitatis (Bendala, 1989-1990: 14-17; Id., e.p.). M. P. García-Bellido ha mostrado su acuerdo con las conclusiones de este último autor y ha subrayado, tanto el carácter púnico de la ciudad de Belo en época republicana, como la ausencia de dedicatorias a Júpiter, Juno y Minerva (García-Bellido, 2001: 326). En la reciente monografía publicada por la Casa de Velázquez sobre los tres templos del foro, se defiende sin embargo, la hipótesis del capitolio, aunque se mencionan brevemente las similitudes observables entre el caso de Baelo y "sanctuaires tripartites de type africain" construidos en ciudades como Sufetula (Sbeitla, Túnez), o Cirta (Argelia) (Bonneville et al. 2000: 183).
} 
bién las tumbas excavadas por J. Remesal en los años setenta del s. XX en la denominada 'necrópolis SE'. En la necrópolis oriental, diversas tumbas se alineaban a lo largo de la vía durante algunos metros, permitiendo contemplar al caminante edículas e inscripciones. Sin embargo, otras muchas -tanto las más sencillas como mausoleos de cierta entidad- se disponían en aparente desorden sobre un área reducida (Mergelina, 1927: 5). Es posible que la superposición de enterramientos de diversas épocas ofrezca hoy un paisaje confuso al contemplar fotografías y planos del lugar donde en algún momento pudo existir, como en otras necrópolis romanas, una red de vías secundarias o diverticula, pero tampoco puede descartarse por completo que la necrópolis oriental de Baelo estuviese regida por un concepto del espacio funerario más cercano al que se puede encontrar en el mundo púnico. Los datos disponibles sobre la necrópolis occidental son mucho más escasos pero, según C. de Mergelina (1927: 5), presentaba una distribución de los enterramientos muy similar ${ }^{8}$.

\section{Los cipos funerarios de Baelo Claudia}

Uno de los elementos más destacados de las necrópolis de Baelo Claudia, por su singularidad y por las dificultades de interpretación que presenta, es el conjunto de piedras talladas asociadas a los enterramientos que se analizan en estas páginas. Los obreros que trabajaban en el yacimiento a principios del s. XX bajo la dirección de P. Paris, G. Bonsor y C. de Mergelina los bautizaron con el nombre de 'muñecos', y como tales se conocen aún hoy en día en la mayoría de la bibliografía especializada sobre el tema. En este artículo se propone emplear el término "cipo", una palabra de origen latino (cippus), que, en mi opinión, además, tiene la virtud de aludir a ciertas características esenciales para comprender la función de las piezas de Bolonia. Los cipos eran pila-

\footnotetext{
8 Algunos enterramientos han aparecido dispersos en otros puntos del yacimiento, aunque generalmente pueden adscribirse a momentos tardíos. Por ejemplo, en el interior de la ciudad se encontraron tres sarcófagos que no contenían ningún ajuar en las termas de la puerta oeste. También se exhumaron dos esqueletos y una estela funeraria al parecer fechada en el s. V d. C. en los niveles del relleno del teatro y al norte de la ciudad dos sondeos realizados en 1966 pusieron al descubierto algunos sarcófagos fragmentados. Finalmente, se tiene constancia del hallazgo de 18 sepulturas de inhumación con orientación este-oeste y un pequeño cofre de piedra a unos ciento cincuenta metros al norte de la necrópolis oriental junto al acueducto procedente de Punta Paloma y la puerta este del asentamiento. Al parecer, sólo se conservaban en el momento de la excavación tres esqueletos en decúbito supino que carecían de ajuar. Las tumbas consistían en sarcófagos monolíticos o fosas delimitadas por materiales de construcción reutilizados o piedras talladas que, en todos los casos, habían perdido ya la cubierta (García y Bellido, Nony, 1969: 472).
}

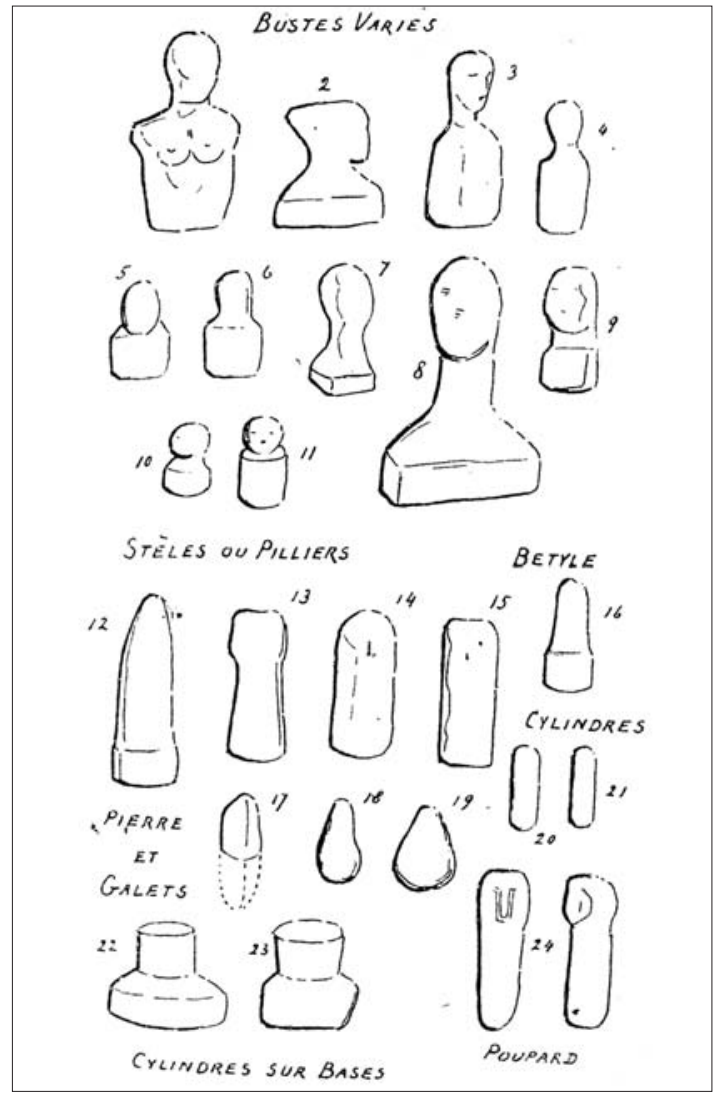

Figura 2. Baelo Claudia. Tipos de cipos funerarios (Según Paris et al. 1926, fig. 65).

res de piedra, a veces sustituidos por pilares de madera (pali sacrificales), que se empleaban para marcar un límite, una frontera, un terreno consagrado o una sepultura (Saglio, 1887; Glare, 1968a). Son por lo tanto, esencialmente, objetos liminales, que señalan el punto de contacto entre dos espacios diferenciados desde un punto de vista ritual y, en el caso concreto de Baelo, entre el inframundo y los miembros vivos de la familia que rinde culto a los ancestros en el punto de contacto entre estas dos esferas que es la tumba.

Estas esculturas presentan una morfología diversa (fig. 2) que puede ir desde formas ovoideas, a tipos estiliformes -con basa o si ella-, pasando por representaciones de carácter antropomorfo asimilables, en menor o mayor medida según sus características, a bustos grecolatinos ${ }^{9}$. Hay ejemplares que apenas alcanzan $\operatorname{los} 15 \mathrm{~cm}$

9 Un reciente intento de sistematización de estas piezas puede encontrarse en la Tesis Doctoral inédita de I. Seco Serra (2003: 635-639), donde propone su clasificación dentro de los siguientes grupos: Anicónico (tipo 1 y tipo 2), Intermedio (tipo 1 y tipo 2) y Antropomorfo (cabeza, busto, cuerpo y cuerpo entero). 

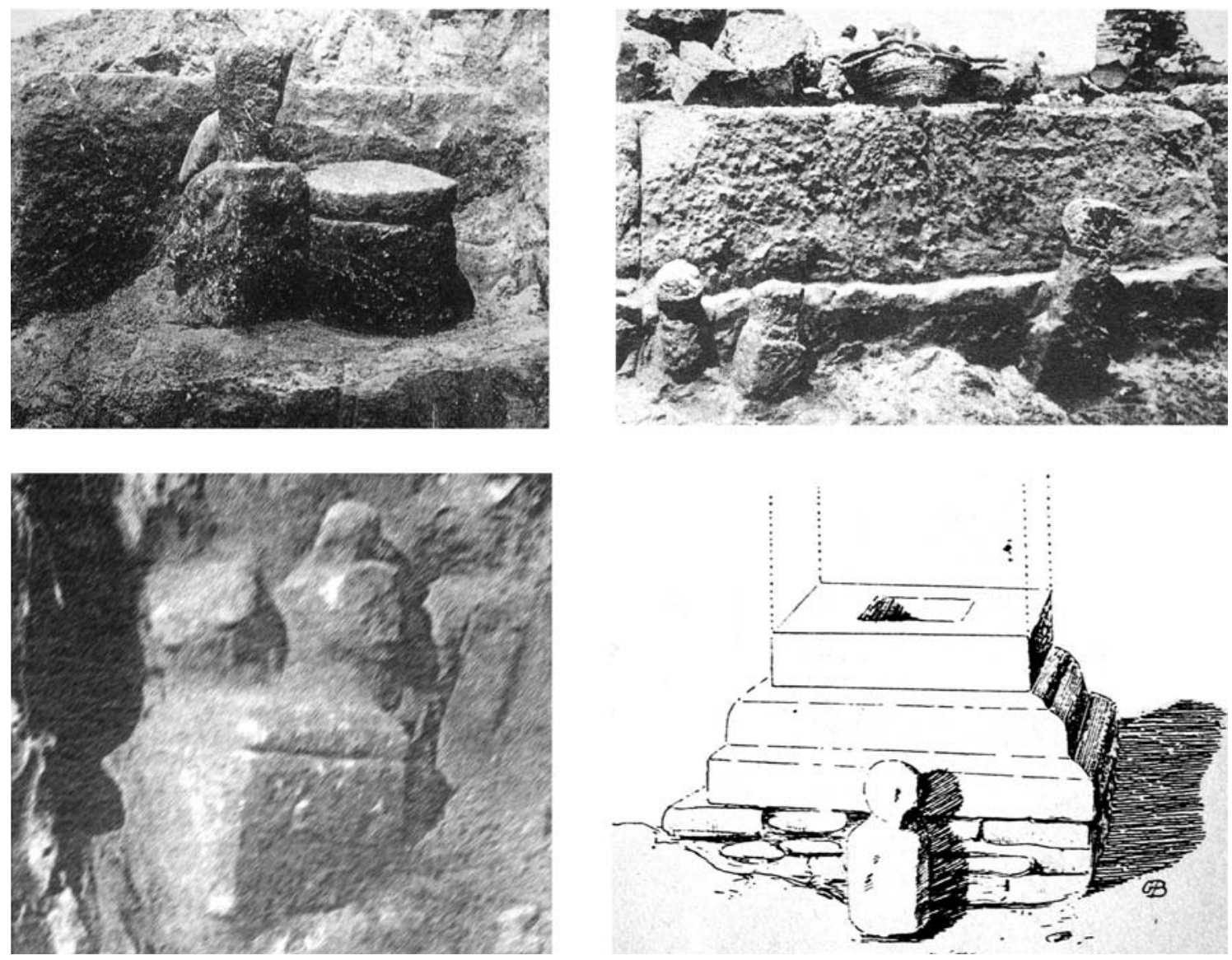

Figura 3. Baelo Claudia. Necrópolis oriental. La ubicación de los cipos directamente sobre el contenedor funerario o en la base de urnas y monumentos -que debía quedar cubierta de tierra- demuestra que muchos serían sólo parcialmente visibles o que incluso quedarían ocultos en algunas ocasiones (imágenes tomadas de Paris et al. 1926; pl. VIII, VII, XII y fig. 17).

de altura, mientras que otros rebasan $\operatorname{los} 40 \mathrm{~cm}^{10}$. Se han fechado con precisión únicamente los ejemplares estudiados por J. Remesal durante las excavaciones de la necrópolis SE de los años setenta del s. XX (gracias a la asociación de los cipos con los ajuares de las tumbas a los que se superponían), entre época de Claudio y de los emperadores flavios ${ }^{11}$ (Remesal, 1979); mientras que al centenar de piezas halladas por el equipo de P. Paris, sólo podemos atribuirles de forma laxa las fechas otorgadas a la necrópolis en su conjunto. Los monumentos

\footnotetext{
${ }^{10}$ En el MAN se conserva una pieza (MAN $3318326 / 15$ / 990) que supera los $60 \mathrm{~cm}$ de altura.

${ }^{11}$ En concreto los "betilos" (según la terminología empleada por J. Remesal) I, II, III, IV, V, VI, VII, VIII y XII, se situarían en época de Claudio, mientras que los "betilos" X y XI, podrían fecharse en época de Nerón / dinastía Flavia. El "betilo" IX no apareció asociado a ningún enterramiento.
}

más tardíos a los que aparecen asociados responden al tipo de cupulae o cupae que no parecen prolongarse en el yacimiento más allá del s. II d. C.

Los 'muñecos' aparecieron asociados tanto a los enterramientos más sencillos (incineraciones en fosa) como a los monumentos más elaborados (pequeños mausoleos, recintos funerarios, cupae), incluida una inhumación (Paris et al. 1926: 68). Se hallaron 'muñecos' aislados sobre tumbas individuales o asociados en grupos de dos, tres, cinco o siete ejemplares que se colocaban, generalmente, en uno de los frentes del monumento funerario. Durante las excavaciones de G. Bonsor, siempre se encontraron en relación con un enterramiento (junto a un contenedor cinerario o sobre él, apoyados en uno de los frentes de los monumentos o encajadas en la propia mampostería que formaba parte de la estructura de la tumba), pero no siempre hay una correspondencia entre número de individuos enterrados y los 'muñecos' que se colocan en el frente de un monu- 

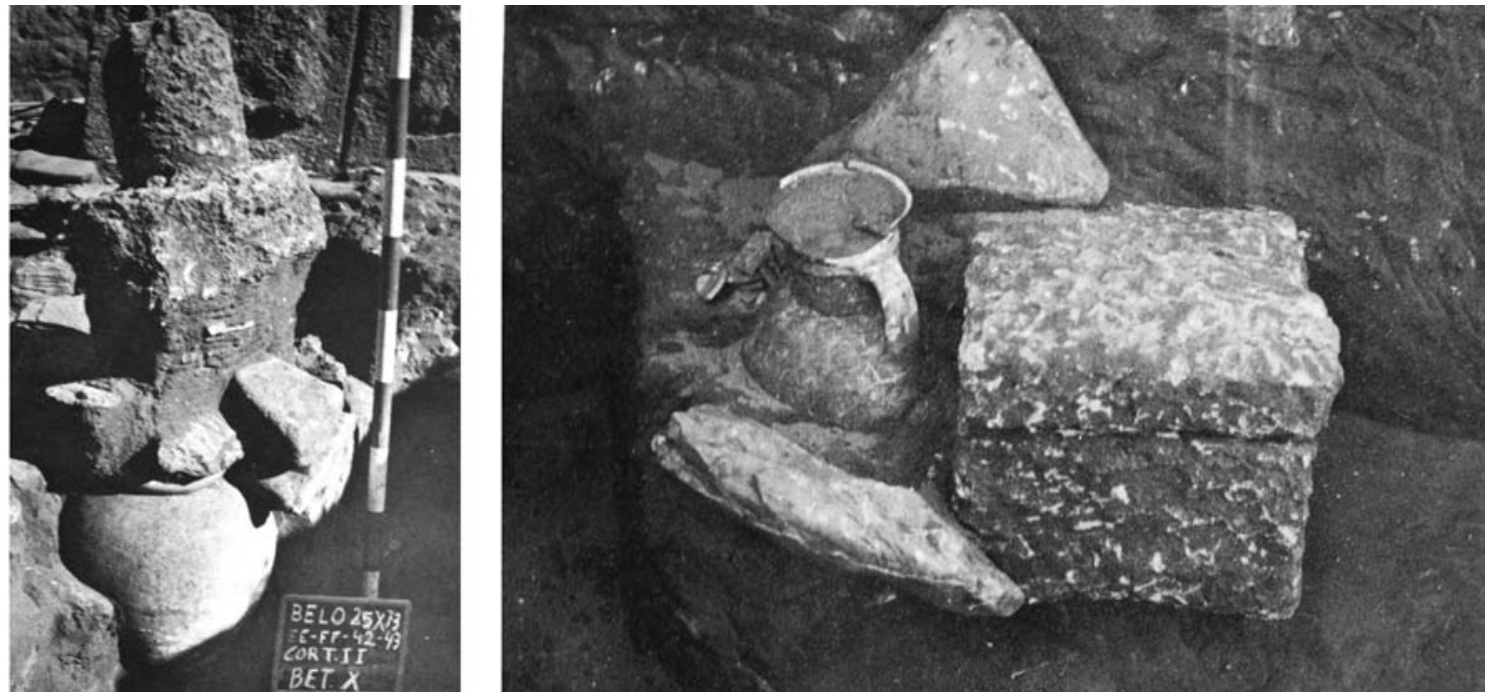

Figura 4. Baelo Claudia. Necrópolis sureste. Izquierda: "Betilo" X situado sobre la urna de la Tumba XVII. La escala permite observar que la distancia que separa el cipo de la urna supera escasamente los $30 \mathrm{~cm}$. Derecha: Piedra tallada de forma triangular que reposa directamente sobre la tumba XVIII (tomadas de Remesal, 1979, láms. 15 y 16).

mento funerario (Paris et al. 1926: 109). Por ejemplo, en la tumba de Felicula se descubrieron dos contenedores cinerarios, pero el monumento contaba con cinco cipos, mientras que en el acotado 963 el número de tumbas superaba con creces al número de esculturas (Paris et al. 1926: 30, 63).

Pero quizá el elemento que define estas piezas con mayor claridad es su ubicación en una especie de limbo o espacio liminal entre la superficie y el subsuelo, semienterradas y apoyadas contra la base de los monumentos, o apenas aflorando de la tierra cuando se colocan sobre una urna. G. Bonsor nos dice: "Ensuite, ils n'étaient pas apparents, ou tout au plus ne laissaient voir su-dessus du sol que leur tête ou même la partie supérieure de leur tête..." (Paris et al. 1926: 108), e incluso sugiere que la "fealdad" de estos "idoles" podría explicarse, al menos parcialmente, por el hecho de que estaban "destinées à rester cachées" (Paris et al. 1926: 109). C. de Mergelina (1927: 12) en la descripción de uno de los monumentos excavados por él mismo asegura que los cuatro cipos funerarios "colocados, como siempre, en el lado que mira al mar", se encontraban "a un nivel inferior a la línea del basamento". J. Remesal (1979: 13), también destacó en su día la existencia de una plataforma que cubría algunos de los cipos situados en la cara sur del Monumento A de la necrópolis SE. La observación de determinadas fotografías e ilustraciones publicadas hasta el momento parece conducir a la misma conclusión (fig. 3).

Éste es un aspecto esencial y característico de los cipos funerarios de Belo, porque permite establecer diferencias entre la ubicación de las estelas que tenían como función principal indicar la posición de la tumba y los denominados 'muñecos' cuyas dimensiones son más reducidas. G. Bonsor, refiriéndose a las estelas halladas en el yacimiento señala: "La plupart de ces pierres étaient encore en place et sous celles-ci, à la profondeur moyenne de 1 mètre, on trouva le plus souvent une sépulture à incinération intacte" (fig. 7, arriba, derecha; Paris et al. 1926: 27). Las estelas se situaban por lo tanto, aproximadamente a un metro del enterramiento que señalizan, mientras que los 'muñecos' se encontraban a una distancia mucho menor de la urna cineraria, según se aprecia en distintas fotografías y dibujos, o incluso a veces quedaban apoyados directamente sobre el mismo plano que esta última (figs. 3, 4). También en el caso del posible "cipo troncopiramidal", encontrado sobre la tumba XVIII de la necrópolis SE, llama la atención la escasa separación entre el contenedor cinerario y lo que parece ser una piedra tallada (fig. 4, derecha). Algunos ejemplares relacionados con incineraciones cubiertas por cupae, se encontraban embutidos, asimismo, en uno de los frentes del monumento (fig. 5). Otros, en fin, denominados "cantos rodados" (galets) por G. Bonsor, de carácter anicónico acusado, habían sido "insertados" o "incrustados" 12 en la base del monumen-

12 “Ce n'est pas tout, et nombre de sépultures parmi les plus récentes, nous ont montré la régression portée plus loin encore, puisque le muñeco est remplacé par un simple galet, que l'on n'a presque jamais choisi pour sa forme rappelant vaguement la silhouette d'un buste, galet que l'on a complètement noyé dans la maçonnerie de la face du tombeau, au-dessus de la table à libations" (Paris et al. 1926: 114). 


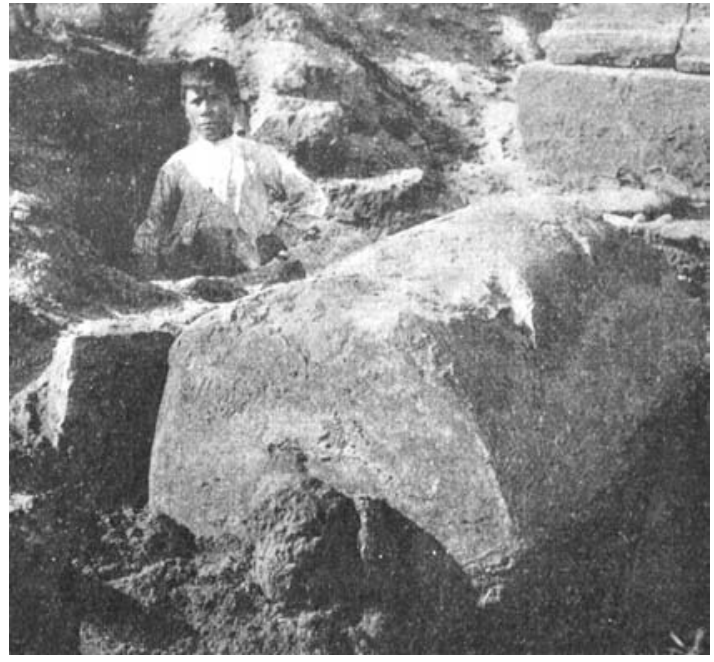

Figura 5. Baelo Claudia. Necrópolis oriental. Cupa con un cipo encastrado en el frente (tomada de Paris et al. 1926, pl. IX).

to o en un pequeño cubículo de la construcción destinado a tal efecto, situado, precisamente, bajo la mesa de libaciones (fig. 6). De hecho, otra particularidad fundamental de estos objetos de piedra es su conexión directa con las libaciones asociadas a los cultos funerarios. Frecuentemente aparecieron junto a conductos de libaciones que permitían el paso de las ofrendas hasta las cenizas del difunto, o rodeadas de fragmentos de cerámica $^{13}$ (Paris et al 1926: 38), hasta el punto de que G. Bonsor llega a sugerir la posibilidad de que las piezas de vajilla empleadas durante el sepelio hubiesen sido "brisés sur la tête même du mystérieux buste de pierre" (Paris et al 1926: 46). En los casos excepcionales en los que aparecen completamente expuestas sobre la superficie de la necrópolis, suele ser posible, asimismo, relacionar estas esculturas con la profusio. Así, por ejemplo, en la "Tumba de la Gran Estela" (Paris et al. 1926: 34), que tenía un 'muñeco' colocado encima de una mesa de libaciones (fig. 7, izquierda), o en algunas cupae como la $\mathrm{n}^{\circ} 372$, donde el busto se situó entre uno de los frentes de la bóveda de medio cañón y su mesa de libaciones. Probablemente, esta vinculación ritual con las libaciones a los muertos es uno de los aspectos que confiere mayor unidad a este conjunto, bastante heterogéneo desde el punto de vista morfológico. Otro elemento común es la orientación hacia el sur, mirando hacia el mar, de la mayoría de estas piedras talladas aun-

13 'Un muñeco, qui se trouvait contre le mur à l'extérieur de l'enclos XXIV, était pour ainsi dire couvert de tessons de patères de cette céramique à glaçure rouge et de l'autre, plus rare, dite jaspée, qui proviennent des fabriques gallo-romaines" (Paris et al. 1926: 38). que se han constatado algunas excepciones ${ }^{14}$ (Paris et al. 1926: 108).

La interpretación de este grupo de esculturas ha estado relacionada desde un primer momento con el concepto que sobre la 'romanización' tenían los distintos autores que han emprendido la difícil empresa de proponer una explicación. "Sont ce des images des morts auxquels on voulait assurer une sorte de survie matérielle?", se preguntaba G. Bonsor. "Cette hypothèse semble impossible à accepter. Nos planches [...] nous dispensent d'insister sur la barbarie de ces bustes, plus affreux les uns que les autres, exécutés par des carriers qui, bien entendu, n'ont jamais eu le moindre sentiment d'art, mais qui semblent même n'avoir jamais regardé une face humaine. Comment admettre que les parents des défunts, vivant à une époque de civilisation raffinée, dans une ville où ne manquèrent pas les sculptures passables (voyez au volume précédent les statues du Capitole), et même belles (voyez les têtes de lions), dont les maisons étaient pleines de produits d'une industrie artistique: bijouterie, verrerie, céramique, aient pu se contenter pour leurs morts de pareils portraits?" 15 (Paris et al. 1926: 107-108). Tras rechazar la hipótesis que relacionaría a los 'muñecos' de Belo con retratos funerarios, G. Bonsor se inclina a reconocer en ellos genios protectores de los difuntos y de la tumba. Según este autor, los genios más antiguos, tendrían un aspecto 'primitivo' que se habría mantenido a lo largo de los siglos debido a "la force de la tradition, surtout en matière de religion et de rite" (Paris et al. 1926: 109). Para explicar este retorno a la tradición "anicónica" de los primitivos pueblos hispanos, G. Bonsor recurre al componente oriental de la

${ }^{14} \mathrm{G}$. Bonsor recoge al menos cuatro casos en que esta premisa no se cumple (recintos 958, 631, 505, 507) (Paris et al. 1926: 47, 55, 64, 66).

15 C. de Mergelina expresa la misma idea con estas palabras: "Lo insólito de nuestra necrópoli, lo que le comunica aspectos de rareza y novedad, de interés y extrañeza particulares, es la presencia, en buen número de sepulturas, de curiosas representaciones que, por sus características de tosquedad, si se desplazaran del medio propio en que aparecen, podrían tomarse como manifestaciones correspondientes a aquellos lejanos períodos del desenvolvimiento humano en que todo son balbuceos, intentos o simples conatos por llegar a conquistar la forma" (Mergelina, 1927: 30). Una opinión inserta en la misma línea de pensamiento se puede encontrar en la publicación dedicada al yacimiento de finales de los noventa de P. Sillières: “¿Qué significado podían tener estos «muñecos»? No es probable que sean representaciones de los difuntos, porque cuesta trabajo admitir que las familias se conformasen con semejantes retratos de sus muertos. Aunque, en último extremo, esto pueda concebirse en el caso de las tumbas más pobres, evidentemente es inadmisible en el de los mausoleos ricos. Para aceptar tal explicación sería preciso haber encontrado algunas esculturas hermosas; pero no es así, y todas estas piedras rivalizan en fealdad" (Sillières, 1997: 200). 

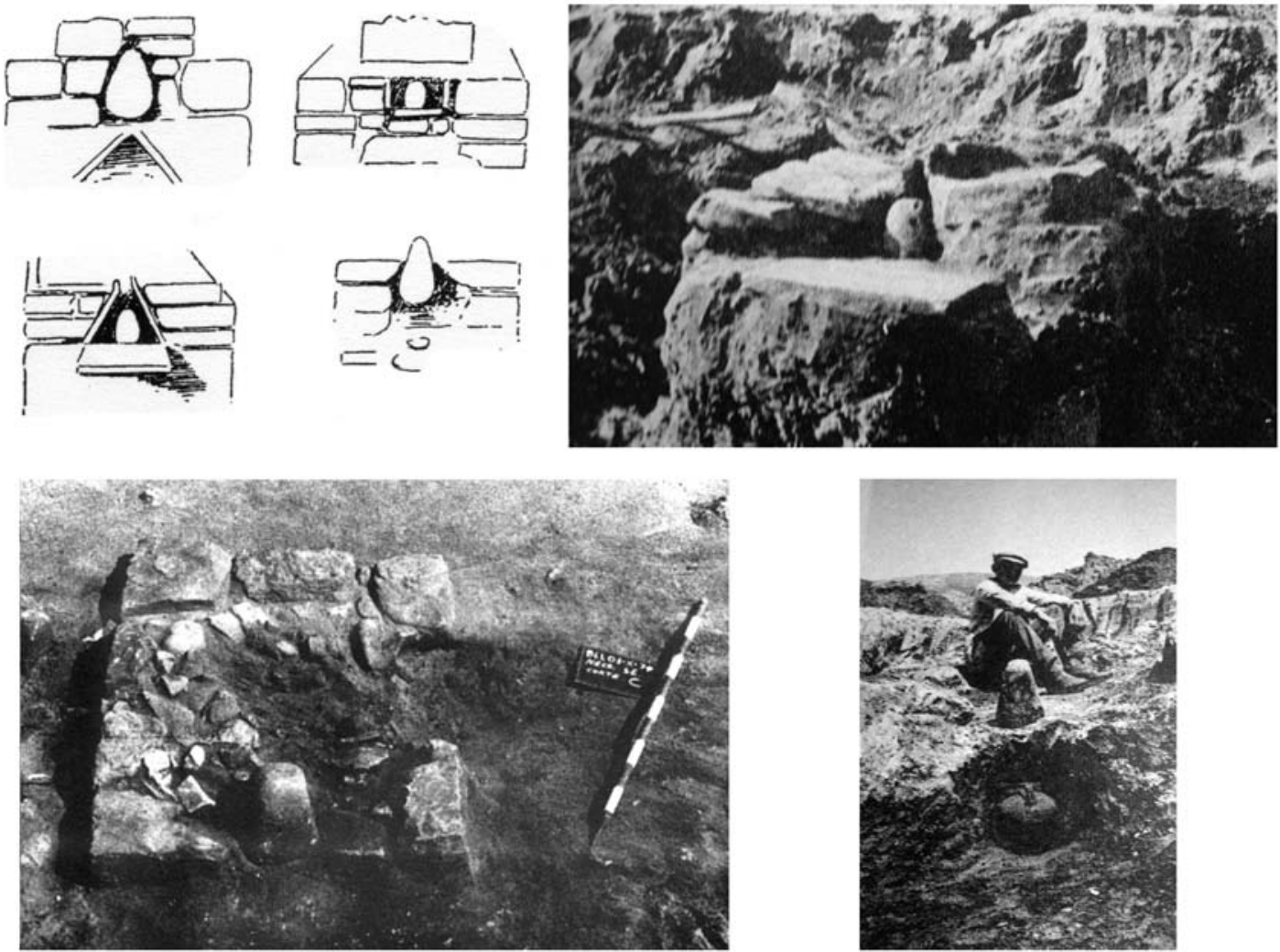

Figura 6. Baelo Claudia. Cipos funerarios integrados dentro de la mampostería de distintos monumentos. Arriba: Necrópolis oriental. Abajo: Necrópolis SE. 'Piedra' troncocónica hallada en la base de un monumento funerario excavado durante la campaña de 1974 (izquierda), similar a otros ejemplares aislados encontrados sobre las tumbas por el equipo de G. Bonsor a principios del siglo XX en la Necrópolis oriental (derecha) (imágenes tomadas de Rouillard et al. 1979, lám. 24 y Paris et al. 1926, fig. 66 y láms. X y IX).

cultura bástulo-fenicia y al estrecho contacto de los habitantes de Bolonia con el norte de África, presentando como ejemplo ilustrativo los 'betilos' embutidos en las cupae de la necrópolis romana del Camp de Sabattier en Susa (antigua Hadrumetum), Túnez. Todo ello le lleva a concluir que tanto para las 'piedras sagradas' de Susa, como para los 'muñecos' de Bolonia puede defenderse un origen púnico (Paris et al. 1926: 113-114).

Por su parte, C. de Mergelina, en una memoria publicada un año después de la aparición de los dos volúmenes monográficos sobre el yacimiento, insiste en la ausencia de paralelos en el sustrato ibérico o en el mundo romano (Mergelina 1927: 30-42). Sin embargo, no comparte la teoría de $\mathrm{G}$. Bonsor de que dichas producciones puedan considerarse genios o representaciones de una divinidad funeraria, protectora de los difuntos, porque en ese caso sería difícil explicar la aparición de distintas esculturas en una misma sepultura y, sobre todo, la gran variedad de tipos que presentan los grupos de 'muñecos' que fueron depositados, a veces incluso en un solo monumento, sin que mediasen intervalos dilatados de tiempo. Según C. de Mergelina, los 'muñecos' de Belo son una representación de los individuos enterrados, que estaría en relación con la necesidad -constatada en varias culturas mediterráneas- de realizar una "réplica" del difunto. El autor rechaza a continuación la identificación de estas esculturas con el genius romano y recuerda que las profusiones realizadas junto a la tumba en época romana no estaban dedicadas a ninguna divinidad protectora, sino a los propios difuntos. También señala -y más tarde volveremos sobre ello-, que los mismos Lares, Manes y Penates estuvieron conectados de alguna manera con la figura de los antepasados y que a ellos se realizaban una serie de sacrificios similares a los que se pudieron constatar en las tumbas de Baelo Claudia.

J. Remesal, por su parte, rechaza la asimilación de los 'betilos' de Belo -como prefiere denominarlos- con retratos funerarios, porque, en su opinión, de ser así, todos ellos habrían tenido un carácter antropomorfo del que muchos ejemplares carecen. Por ello recupera la teoría de $\mathrm{G}$. Bonsor que vinculaba estas piezas -de tradición prerromana influida por costumbres púnicas-, a genios 

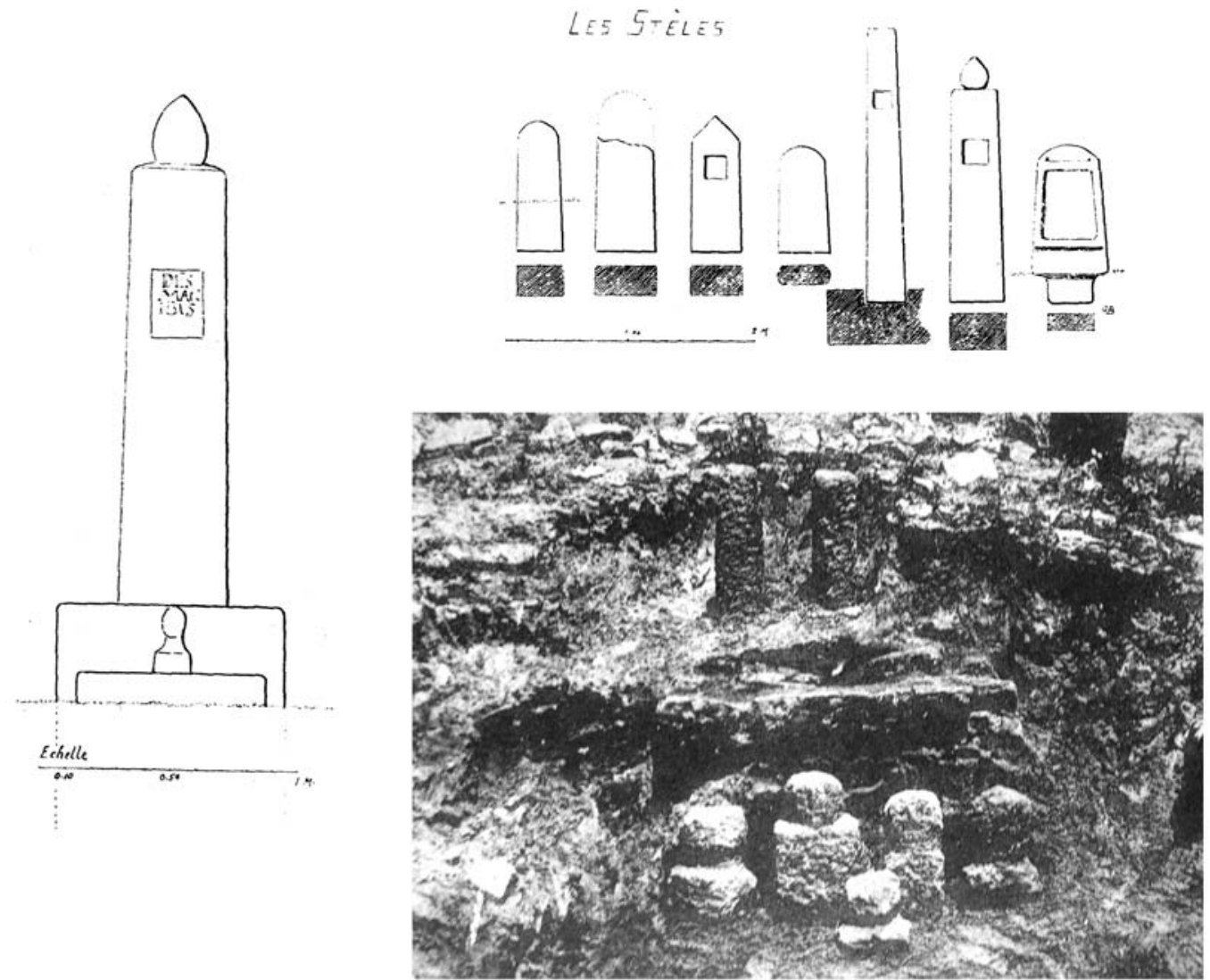

Figura 7. Baelo Claudia. Tipos de estelas presentes en el yacimiento (arriba, derecha) Necrópolis oriental. Tumba de la Gran estela, el "muñeco" se ha situado a los pies de la estela, sobre una mesa de libaciones (izquierda). Necrópolis oriental. Tumba de base cuadrangular con varios "muñecos" en el frente y coronada por dos estelas 'betiliformes' (abajo, derecha) (todas ellas tomadas de Paris et al. 1926, figs. 21, 14 y pl. VII)).

protectores relacionados con divinidades de ultratumba y señala paralelos, por ejemplo, en lugares como la necrópolis de Puerta Cesarea en Tipasa, Tiddis, Volúbilis, Sétif, Camp Sabattier y Cádiz. Aunque encuentra dificultades a la hora de proponer una divinidad en concreto, sugiere una posible relación con cultos a Saturno, Baco, una divinidad marina, infernal o quizá a alguna deidad del panteón púnico y recuerda que, según su opinión, uno de los ejemplares encontrados en la intervención de 1973 pudo tener un carácter fálico, asociable "con símbolos de la vida futura" (Remesal, 1979: 42-44).

Recientemente, en un artículo dedicado a analizar el peso de la tradición púnica en los enterramientos romanos del sur peninsular, D. Vaquerizo ${ }^{16}$ ha defendido la

${ }^{16} \mathrm{D}$. Vaquerizo ha mostrado su acuerdo con algunas de las afirmaciones incluidas en este mismo trabajo y en mi Tesis Doctoral defendida en la Universidad Autónoma de Madrid en noviembre de 2005 (Dir. Manuel Bendala Galán). Ver, específicamente: Vaquerizo, 2006: 354-355, notas 100 y 101. hipótesis de que estas piezas “...pretenden evocar la imagen del fallecido, quizá con un alto componente norteafricano en cuanto a su estilo y ejecución material, pero similares en concepto a las estelas y retratos documentados en algunas necrópolis del golfo de Nápoles..." sin descartar por ello que, en ocasiones, estas tallas "sean realmente betilos, con un simbolismo religioso que pretendía encomendar al difunto a una determinada divinidad" (Vaquerizo, 2006: 351-352 y nota 97).

En el caso de los cipos funerarios de Belo el problema interpretativo, como hemos podido ver, comienza incluso con la expresión que se emplea para definirlos, ya que por diversas razones, los términos "estela", "bustos" o "betilo" no son adecuados en este caso. Es difícil referirse a estas piezas en su conjunto como "bustos", porque, si bien algunos ejemplares podrían responder de forma laxa a este tipo, esta expresión no se puede utilizar con rigor para referirse a todos aquellos de carácter anicónico. Las excavaciones llevadas a cabo a principios de los años setenta del siglo XX tuvieron la vir- 
tud de demostrar precisamente, a través de técnicas estratigráficas modernas, que cipos pertenecientes a ambos grupos convivían en el tiempo y eran utilizados para la misma función (Remesal, 1979: 42), lo que permite descartar que los anicónicos deban interpretarse como una evolución morfológica de los antropomorfos, o a la inversa. Por las mismas razones, y no por el mayor o menor acierto estético de los cipos antropomorfos en relación a supuestos modelos grecolatinos, parece difícil defender una asimilación completa de estas piezas con los retratos funerarios que se encuentran en algunos monumentos romanos. Como ya indicó G. Bonsor, no parece posible hablar, en el caso de Baelo, de limitaciones técnicas a la hora de tallar la piedra, sobre todo si tenemos en mente algunos de los hallazgos escultóricos que ha proporcionado la ciudad. En mi opinión hay que pensar, más bien, en una elección consciente de representaciones no "naturalistas", con mucha probabilidad relacionada con cuestiones rituales y con la utilización de modelos formales de corte arcaico ya en su tiempo.

Los cipos funerarios de Belo no son estelas, en primer lugar porque no responden a la forma paralepípeda propia de este tipo de monumentos, que, por otro lado, también fueron utilizados en las necrópolis (fig. 7 arriba, derecha); pero además, y esto quizá es más importante, porque, excepto en contadas excepciones, no cumplen la función de sema, de señalar el lugar de enterramiento de un individuo concreto a través de un monumento claramente visible. Una de las características rituales fundamentales de estas esculturas de pequeño tamaño (la gran mayoría, recordémoslo, oscilan entre los 15 y los $40 \mathrm{~cm}$ ), es su ubicación en un espacio liminal, semienterradas en el suelo, poniendo en comunicación el mundo terreno con el infraterreno. El depósito, por parte de los oferentes, de varias de estas piezas en enterramientos individuales o la imposibilidad de establecer una correlación entre el número de cremaciones y el número de cipos cuando nos encontramos ante enterramientos colectivos, refuerza el mismo argumento. Pero, por si todo ello fuese poco, conocemos al menos un caso, el de la tumba de la gran estela -precisamente uno de los pocos donde el 'muñeco' no se encontró semienterrado o embutido en la mampostería de la construcción- en el que uno de estos ejemplares se situó precisamente en una mesa de libaciones colocada a los pies de una estela. Esta posición carecería de toda lógica, si el 'muñeco' hubiese cumplido la función ritual de este tipo de monumentos funerarios (fig. 7, izquierda). Aunque no aparece explícitamente citado en el texto de G. Bonsor, no podemos tampoco dejar de mencionar que en una de las láminas de la memoria se puede observar lo que parecen ser dos estelas betiliformes -muy similares, por cierto, al tipo de estela anicónica frecuente en muchas necrópolis púnicas ${ }^{17}$ - situadas sobre una tumba que contaba con cinco 'muñecos' en uno de sus frentes (Paris et al. 1926: Pl. VII, arriba, derecha) (fig. 7 abajo, derecha).

Según un estudio reciente sobre el fenómeno betílico en la península ibérica, a cargo de I. Seco ${ }^{18}$, los cipos de Belo tampoco pueden ser identificados como betilos en sentido estricto. Con este término se alude a aquellas piedras no alteradas por la mano del hombre o talladas en forma cónica, cuadrangular, ovoidea, troncocónica o estiliforme que se creían habitadas por la divinidad y a las que se rendía culto mediante una serie de rituales de carácter muy específico (Seco, 2003: 204). No obstante, especialmente en el mundo púnico, se produjo cierta convergencia en la forma de determinadas piezas que indicaban la posición de un enterramiento y algunas cla-

\footnotetext{
${ }^{17}$ Me refiero a un conjunto de estelas muy difundidas en necrópolis y tofets del mundo fenicio-púnico colonial, que desempeñaron, fundamentalmente, la función de sema y cuya morfología puede, en ocasiones, presentar concomitancias con la de los betilos de la región. Si bien poseen una cronología elevada en comparación con las piezas de Belo, es posible datar algunos ejemplares en el s. II a. C. (Bisi, 1967). Se pueden citar, como mero ejemplo ilustrativo de este gran conjunto de materiales, determinadas estelas sobre base cuadrangular de Sulcis (Bartoloni, 1986: Tav. I-IX), Tarros (Moscati, Uberti, 1985: Tav. VII.), o Mozia (Moscati, Alberti, 1981: Tav. XVIII, $\mathrm{n}^{\mathrm{o}} 119,120,124,126$,), que recuerdan fundamentalmente a los ejemplares sin rostro ('columna' sobre basa cuadrangular o redondeada) procedentes de Belo. Existen mayores dificultades a la hora de encontrar estelas semejantes a los cipos funerarios de Bolonia que presentan rasgos antropomorfos. Se puede señalar, sin embargo, un conjunto reducido de losas de piedra con la representación de un pequeño rostro humano con largo cuello, que resultan excepcionales incluso dentro del conjunto de manifestaciones funerarias de las necrópolis a las que se encuentran asociadas y, en ocasiones, pueden situarse en época republicana o altoimperial, como los cipos de Baelo. Véase Tore (1975, tav. XI.3), Moscati (1995: tomo I, 394-399, tav. 110-112; tomo II, 530-541, tav. 157-184), Bondi, (1972: pl. LVII.1), Picard, (1967: 303, Cb-1090, pl. CXXVII) y Sader (2005, estelas 9, 44, 46, 47 y 50). Estas estelas parecen demostrar, que también en determinados enclaves del mundo púnico, se empleó la cabeza para representar de forma sintética al difunto o a ciertos númenes. No debe pasarse por alto la tendencia a añadir rasgos humanos a ciertos símbolos del imaginario fenicio-púnico (como el ídolo botella), o algunos intentos de dotar a los betilos de ojos y boca (Lipinski, 1992: 71, 227; Tore, 1975: 298). En cualquier caso, al volver la vista al contexto inmediato de los cipos funerarios de Baelo Claudia, llama la atención, la escasez de estelas funerarias púnicas halladas en nuestro país en comparación con otros enclaves del Norte de África, Sicilia o Cerdeña, por no entrar en el controvertido asunto de la ausencia de tofets en los asentamientos feno-púnicos del occidente Mediterráneo. Se puede consultar Belén (1992-1993 y 1994) donde se encuentra citada la bibliografía más relevante sobre este aspecto.

${ }^{18}$ Le agradezco a la autora que me haya permitido consultar
} su Tesis Doctoral, aún inédita. 
ses de betilos, lo que ha propiciado el uso de términos como el de "estelas-betiliformes" ${ }^{19}$. Sin embargo, y esto es fundamental, dichas estelas, no pueden ser consideradas imágenes cultuales, aunque se aluda de forma directa a la manera canónica de representación anicónica de la divinidad. Se ha señalado que detrás de la equivalencia formal de estos 'hitos' de carácter religioso pudieran encontrarse distintos conceptos de 'heroización' del difunto. Lo que parece al menos probable en determinados casos es que estas piezas puedan compartir un elemento esencial con los betilos: la idea de que la piedra puede convertirse en una 'casa del alma', o lo que es lo mismo, que determinados rituales pueden llevar a los espíritus a hacer del betilo una 'piedra habitada' (Seco, 2003: 234, 651, 652).

Incluso si se quisiera argumentar que en el caso de Belo nos encontramos ante la utilización no de verdaderos betilos, sino de estelas betiliformes, nos encontraríamos con la dificultad de explicar por qué estas supuestas estelas se encontraban semienterradas y por qué cuando aparecen agrupadas, como ha señalado I. Seco, no parecen responder en todos los casos a las asociaciones betílicas más frecuentes en el mundo púnico: díadas, tríadas o parejas de tríadas. A pesar de todo ello, contamos con un ejemplo, que se acaba de mencionar, que sí parece poder relacionarse directamente con las representaciones de díadas betílicas que aparecen en numerosas estelas púnicas. Lo más interesante, es que, en este caso, las dos estelas betiliformes se encuentran en superficie, señalando la ubicación de la tumba, y no por ello se ha prescindido de colocar una serie de 'muñecos' en la base del monumento cuadrangular que contendría las cenizas (Paris et al. 1926: Pl. VII, foto superior derecha) (fig. 7, abajo, derecha). Todo ello parece subrayar, una vez más, la relación de carácter complementario (que no equivalente) existente entre la estela o estela betiliforme y los cipos funerarios de Baelo. La diferencia esencial entre ambos reside en su función ritual: mientras que las estelas betiliformes pueden considerarse un elemento que señala la posición del enterramiento y que se ha 'apropiado' de la morfología de un objeto presente en contextos sacros (el betilo), los cipos de Bolonia deben considerarse un objeto 'cultual' en sí mismos, aunque el tipo de culto que reciben no es análogo al conjunto de ritos específicos que se desarrollaba en torno a la imagen betílica de un santuario.

\section{Cipos funerarios púnicos}

A la dificultad para encontrar un término aceptable para estas representaciones se une el carácter de unicum

\footnotetext{
19 Ver nota 17
}

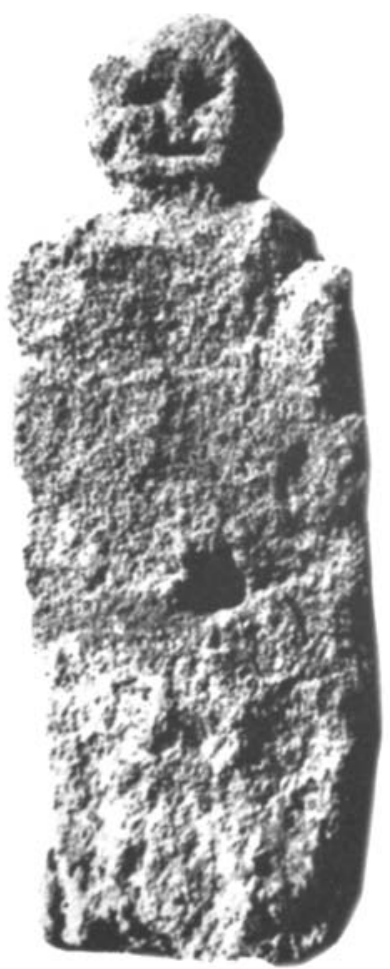

Figura 8. 'Estela' hallada en el interior de la tumba 27 de la necrópolis de Lilibeo (Sicilia) (Según Bisi, 1971: fig. 83).

que presenta este conjunto de esculturas en el panorama de la arqueología del mediodía peninsular. Baelo Claudia continúa siendo un caso totalmente excepcional, tanto por el número de tallas de este tipo que se han recuperado en sus necrópolis, como por el mismo hecho de que las piezas se encontraran en su contexto original durante el proceso de una excavación arqueológica. En los años veinte, G. Bonsor almacenó más de cien y J. Remesal encontró, medio siglo después, una docena de piezas. Como consecuencia, este último autor y otros después de él, propusieron una serie de paralelos en diferentes yacimientos púnicos del Mediterráneo que se comentan a continuación porque permiten situar las piezas que nos ocupan en un contexto más amplio y añadir algunas observaciones interesantes para comprender un fenómeno que en mi opinión debe, como expondré a continuación, interpretarse no obstante principalmente dentro del marco local de la ciudad que le dio forma, tanto por cuestiones cronológicas como rituales.

Uno de los ejemplos más citados en relación con el ritual funerario observado en Bolonia es el de la estela de la tumba 27 de Lilibeo (Sicilia) (fig. 8). Sin embargo, hay varios aspectos que dificultan una identificación directa. La pieza de Lilybaeum es en sí misma un caso 

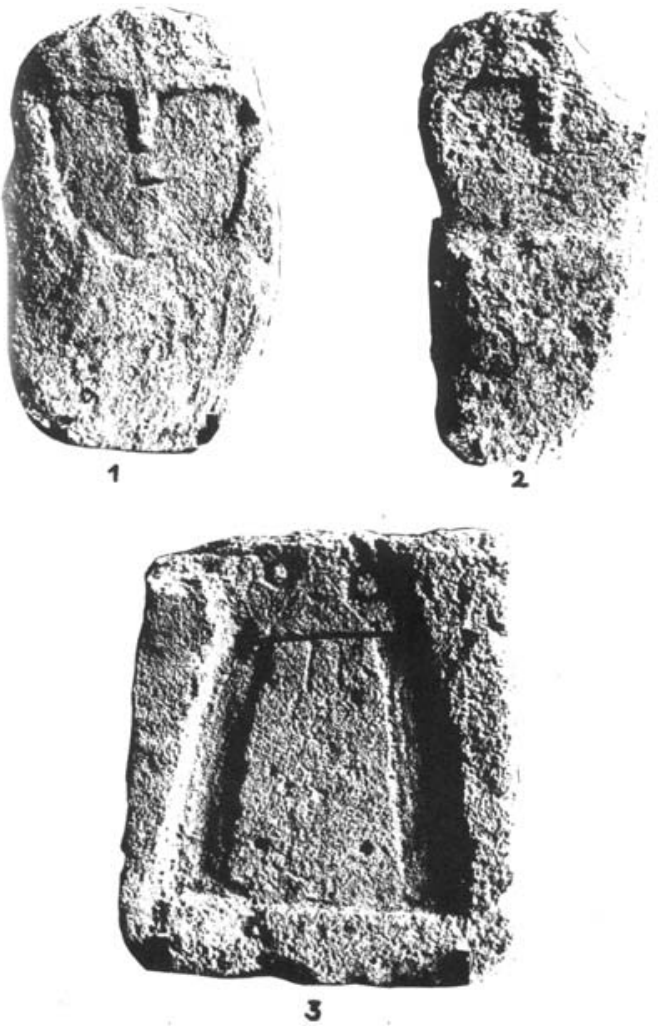

Figura 9. Estelas sardas de época 'púnico-romana' (Según Tore, 1975: tav. XI).

único dentro de la necrópolis ${ }^{20}$, y tanto la cronología mediados o finales del s. III a. C.- como sus dimensiones $-53 \mathrm{~cm}$ de alto, $20 \mathrm{~cm}$ de ancho y $13 \mathrm{~cm}$ de grosorla alejan un tanto de los numerosos ejemplares de Baelo Claudia, en general de tamaño más reducido, bulto redondo y cronología altoimperial. La escultura funeraria de Lilibeo apareció asociada a una de las tumbas en lóculo excavadas en el tufo, pero, curiosamente, había sido introducida por completo dentro del nicho, junto a cinco urnas cinerarias acompañadas de distintos objetos de ajuar. La pieza presentaba además, lo que parecía ser un brazo alzado, en un gesto documentado en otros ejemplares de escultura funeraria fenicio púnica (Benichou-Safar, 1982: 74, fig. 40), y un orificio para encastrar un falo. Según A. M. Bisi, esta característica sugiere cierta relación con modelos tomados de la coroplastia fenicio-chipriota, como las estatuillas de la técnica

${ }^{20} \mathrm{El}$ yacimiento siciliano no ha proporcionado más estelas de época helenística, ni de este tipo, ni de ningún otro, a excepción de un pequeño grupo de estelas votivas procedentes, con bastante probabilidad según publicó A. M. Bisi (1971: 742), del tophet cercano al Timpone di S. Antonio. snow-man, con órganos sexuales aplicados de la Isla Plana (Ibiza), Bithia y Monte Sirai ${ }^{21}$ (Bisi, 1970; Id., 1971).

Mayor cercanía cronológica y en la longitud de las piezas, presentan un grupo de estelas estudiadas, entre otros, por G. Tore (1975) y S. Moscati (et al. 1992; 1995: t.I, 394-399, t.II, 530-541) (fig. 9) de época 'púnico-romana' (ss. III-II a. C.) y altoimperial procedentes de distintas necrópolis sardas. Dentro del grupo, hay varios ejemplares en los que se han trazado de manera somera los rasgos de un rostro mediante incisiones, mientras que en otros -los más cercanos morfológicamente al grupo de Belo-, aparece un busto de carácter esquemático en bajo relieve, o los límites de la propia estela se tratan como si fueran los contornos de la figura humana. Respecto a la interpretación de dichas estelas, G. Tore (1975: 304), relaciona dos piezas de su catá$\operatorname{logo}^{22}$ con una representación simplificada de máscaras de carácter demoníaco, mientras que duda entre identificar el resto con retratos de difuntos o algún tipo de demonio-divinidad protectora de los muertos (Tore 1975: 313). La falta de paralelos formales para estas piezas en el mundo púnico -si exceptuamos, según este último autor, el cipo de Lilibeo y los ejemplares votivos del santuario de Démeter Malophoros en Selinunte ${ }^{23}$, le lleva a concluir que nos encontramos ante el producto de talleres independientes, responsables de manifestaciones sustancialmente autónomas inspiradas en tradiciones púnicas.

La conexión establecida por G. Tore entre algunas estelas funerarias sardas y las 'estelas votivas' del santuario 'della Malophoros' en Selinunte merece, al menos, un breve comentario sobre este controvertido grupo de piedras esculpidas. Estas piezas fueron talladas en el contexto de la expansión púnica por el área occidental de Sicilia a partir de 409 a. C. y la creación de asentamientos en lugares como Panormo, Solunto, Erice, Motzia o la propia Selinunte, que convivieron con colonias griegas y núcleos nativos, al menos hasta la conquista de la isla por parte de Roma a mediados del s. III a. C. En primer lugar, hay que señalar que este conjunto de estelas fueron halladas en un recinto

\footnotetext{
${ }^{21}$ Quizá sea aventurado proponer una explicación para la extraña ubicación de la pieza, pero es tentador pensar en algún tipo de ritual de sustitución, quizá en un caso en el que fue imposible recobrar el cuerpo del difunto.

${ }^{22}$ Fig. T. XII.3 y T. XIII. 1.

${ }^{23}$ El Museo del Bardo conserva una pieza (Picard, 1967: 43, Ca-23 / C-1-D-603, pl. IX), desgraciadamente, de procedencia desconocida, fechada en el s. V a. C. a partir del estudio de los caracteres púnicos grabados en el reverso, que puede considerarse cercana, tanto por el estilo de la ejecución como por el tamaño, a varios de los ejemplares sardos estudiados por G. Tore.
} 
aparte, situado en el exterior del temenos de la diosa, y dedicado a otra divinidad de carácter infernal, Zeus Meilichios, cuyo culto estuvo muy difundido en las colonias griegas de occidente, según algunos autores, en conexión con la propagación de cultos eleusinos. El santuario se fundó al parecer en época griega, aunque el culto prosperó también durante el período de dominación púnica, remontándose a esta época la mayoría de los 'ex-votos' a los que se podría aludir como paralelo de los cipos de Belo. E. Grabrici encontró, a principios del s. XX, al pie de cada estela "un gruppetto di frammenti di piccoli vasi bruciati e rotti insieme con ossa di animali anche bruciati" ${ }^{24}$. Las 'estelas' sicilianas responden a tres tipos principales: piedras donde se tallaron -con "rudesse maladroite", si tenemos en cuenta la 'calidad' de las obras de arte que ha proporcionado el yacimiento de Selinunte (Picard, 1943: 110)- dos rostros, uno femenino y otro masculino; figuras simples con representación de un solo individuo y, finalmente, ejemplares totalmente anicónicos. Al parecer algunas piezas conservaban además restos que inducían a pensar en una decoración con vivos colores, mientras que otras portaban inscripciones. En un reciente estudio, M. L. Famà y V. Tusa han propuesto datar las piezas anicónicas más antiguas en la transición entre los siglos VII y VI a. C., aunque no descartan que alguna de las piezas de este tipo deban situarse en el s. III a. C. (Famà, Tusa, 2000: 19).

Estas estelas han sido a menudo interpretadas como cipos votivos, en los que se representaría al titular del santuario que conocemos gracias a la epigrafía, Zeus Meilichios, y su paredro, supuestamente Deméter Malophoros, siguiendo las propuestas de M. M. P. Nilsson y E. Gabrici. Sin embargo, Ch. Picard (1943) ha puesto en duda la posibilidad de identificar la figura femenina de estos cipos con Deméter, fundamentalmente porque los recintos de ambas divinidades estaban separados y no se ha podido encontrar ningún epígrafe votivo dedicado a Deméter Malophoros en el santuario de Zeus Meilichios. Este autor, de hecho, defiende la idea de que los individuos representados en el 'campo de estelas' no pretenderían evocar directamente a la divinidad, que normalmente se asocia a un tipo iconográfico bastante concreto -el dios barbado suele aparecer sentado en su trono ciñendo un cetro y sujetando en su mano una pátera o el cuerno de la abundancia- sino que se encontrarían más cercanos a la idea del colossos o 'estatua-menhir', que se erigía a veces sobre los cenotafios para sustituir al cadáver del

\footnotetext{
${ }^{24}$ E. Grabrici (1927): Il santuario della Malophoros a Selinunte, MonAL, XXXII, p. 156. Citado en Famà, Tusa (2000: 17).
}

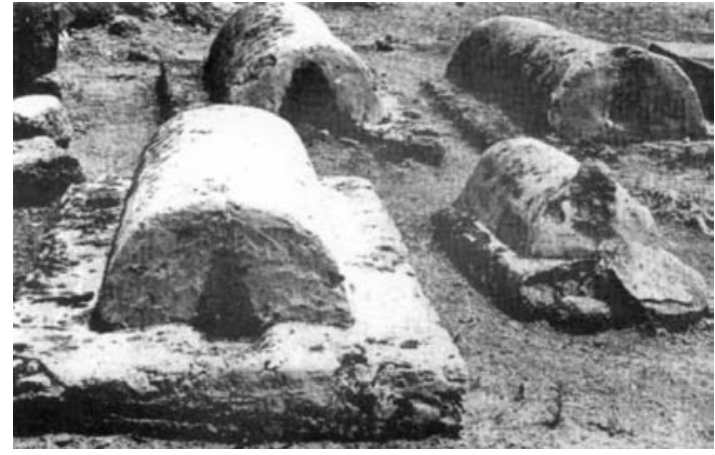

Figura 10. Cupae con piedras talladas encastradas en el frente de la necrópolis de la puerta Cesarea de Tipasa (según Lancel, 1970: fig. 11).

difunto que no había podido ser recuperado. Mediante determinados rituales se podía transformar estos 'recipientes pétreos' en 'piedras animadas' por el alma del ser querido y ausente. Ch. Picard pone incluso en entredicho el carácter votivo de estas tallas, destacando la naturaleza ctónica e infernal de Zeus en su advocación como Meilichios y la ubicación de las piezas junto a la vía de la necrópolis ${ }^{25}$. En las inmediaciones de su santuario en Selinunte, aparecieron, como es habitual en cementerios u otros puntos de comunicación con el 'inframundo', gran cantidad de cerámica fragmentada ritualmente tras las libaciones y un buen número de tabellae defixionum.

Curiosamente, Meilichios, dios y daimon simultáneamente, posee algunos atributos y funciones similares a los de otras divinidades a la vez 'domésticas' y ctónicas del mundo antiguo (como los mismos Lares romanos) que podrían compartir ciertas características rituales, como luego veremos, con los muñecos de Baelo. Meilichios, que a veces es representado bajo la forma de una serpiente, era el genio relacionado con el fuego del hogar y con la protección de los miembros de la familia. Ya hemos mencionado la ubicación de sus santuarios en las vías funerarias, pero además sabemos que en algunas regiones de Grecia los sacrificios ofrendados al dios tenían lugar en festividades asociadas al duelo o al luto. El signo dual, de divinidad de carácter agrario y ctónico, de dios que porta el cuerno de la abundancia y es a la vez considerado 'señor' de los manes, no es en absoluto contradictorio, como nos recuerda Ch. Picard (1943: 105, 118), y como demuestra la asimilación de ambos conceptos también en el caso de los Lares latinos.

${ }^{25}$ Ch. Picard (1943: 117), cita otros ejemplos, tanto en Atenas como en el Pireo, en el que el santuario de Meilichios fue ubicado junto a la necrópolis del asentamiento. 
J. Remesal (1979: 44) defendió, en su estudio de los materiales de la necrópolis sureste de Belo, la existencia de otros paralelos norteafricanos, hallados en yacimientos como Volúbilis ${ }^{26}$, Tiddis ${ }^{27}$, Setif ${ }^{28}$ o Tipasa. En mi opinión, las semejanzas más interesantes -por cierto, ya de época plenamente romana- pueden observarse en este último caso (fig. 10). En la necrópolis de la puerta de Cesarea de Tipasa han sido halladas, como en Baelo Claudia, un conjunto de monumentos tipo cupae con piedras talladas de forma troncopiramidal encastradas en la cabecera de estas construcciones ${ }^{29}$, que se orientan siempre hacia el Oeste ${ }^{30}$. En Baelo Claudia, la gran mayoría de los cipos están orientados hacia la costa, que en ese punto del litoral gaditano se sitúa hacia el Suroeste y, como en el norte de África, quedaban semi-integrados o apoyados contra la mampostería

${ }^{26}$ De Volúbilis procede, en efecto, un cipo de época republicana aparecido en un contexto poco claro, aunque identificado por M. Ponsich con un área de necrópolis. No se menciona, sin embargo, la asociación de este "autel-colonne" con restos humanos que pudiesen confirmar definitivamente su carácter funerario. La morfología de la pieza (una columna sobre basa cuadrangular), recuerda sin duda a algunos ejemplares de Belo, aunque el cipo de Volúbilis posee una serie de molduras que no están presentes en aquéllos. (Ponsich, 1966).

${ }^{27}$ Existen dificultades para asimilar los cipos de Belo a la estela de la necrópolis oriental de Tiddis (Février, 1970: 51) que presenta remate triangular, un conjunto de símbolos vegetales, elementos de carácter simbólico y una inscripción, aunque sin duda resulta interesante la ubicación de la estela en el centro de un círculo de piedras -con la frontal a menor altura, quizá para ser utilizada como mesa de libaciones- que le confiere una particular posición entre el cielo y la tierra que recuerda a la de los cipos rodeados de guijarros que encontró J. Remesal en la necrópolis sureste de Baelo Claudia en los años setenta del siglo XX.

${ }^{28}$ En la necrópolis de Sétif, donde están presentes los tipos de estelas más frecuentes en el mundo púnico, con símbolos tan habituales como los crecientes o los familiares remates triangulares, se encontró también "quelque fois une petite stèle, pierre plate dressée" de carácter más o menos irregular que señalaba el emplazamiento de la sepultura. En algunas ocasiones, como hemos visto ya en Tiddis, se conservaba, delante de estas piedras apenas desbastadas, una losa en posición horizontal, que podría haber sido empleada, según P. -A. Février y A. Gaspary (1966-1967: 21, fig. 12), como una pequeña mesa de ofrendas.

${ }^{29}$ En casos excepcionales alguna de estas "estelas" se "apoyaban" sobre uno de los lados del monumento, en vez de quedar embutida en el frente (Lancel, 1970: 171, nota 4).

${ }^{30}$ Según S. Lancel (1970: 161), este hecho responde a un motivo ritual: "le mort est ici non plus inhumé, mais posé sur le bûcher funèbre la face tournée dans la direction du soleil levant, et la cupule construite à l'emplacement des cendres du bûcher en reproduit l'orientation, avec une légère déclinaison vers le nord-est ou le sud-est où l'on es en droit de reconnaitre une indication sur la saison de l'année où s'est produit le décès". del monumento ${ }^{31}$. Los betilos de las cupae de Tipasa también recibieron libaciones y muy probablemente ofrendas depositadas en el reborde occidental en forma de mensa -similares a los documentados en Bolonia- de algunas de las cupae. Al parecer en Tipasa no convivieron, como en las cupae de Belo, tallas anicónicas con otras de carácter antropomorfo. Si bien hay que recordar, respecto a la morfología de los cipos funerarios asociados a cupae del yacimiento gaditano, que C. de Mergelina (1927: 6-9) se refiere a ellos de forma mayoritaria como "piedras informes" y G. Bonsor los denomina "galets", por la similitud de muchos de ellos con simples guijarros (Paris et al. 1926: 75, 114).

Como hemos visto, por lo tanto, las piezas de Belo en conjunto no se ajustan exactamente a ningún modelo descrito en necrópolis del mundo fenicio-púnico, y, sin embargo, aquéllas que se pueden inscribir en el grupo de las tallas anicónicas sin duda beben en parte de modelos orientales y de la tradicional asociación en las necrópolis norteafricanas y centro-mediterráneas entre las 'estelas betiliformes' y la tumba, entre la piedra que puede ser habitada por el alma y el lugar donde reposan los restos de un individuo. Tampoco es totalmente ajena al mundo oriental la tendencia a añadir rasgos antropomorfos a estelas betiliformes que, no obstante, conservan de forma mayoritaria un carácter anicónico.

3. Cipos funerarios de época republicana hallados en la península italiana

Hasta ahora se ha prestado, lógicamente, especial atención a los paralelos orientales por el pasado púnico del yacimiento gaditano que estudiamos en estas páginas. Pero no menos importante, para entender este fenómeno tan específico de la ciudad de Belo, es tener en cuenta la interacción de los habitantes de la antigua Bolonia con gentes llegadas desde la península italiana. La presencia de piezas en necrópolis italianas de época republicana de morfología muy similar a las que se encuentran en Bolonia o en necrópolis y tofets de yacimientos púnicos (Blumhofer, 1993: anexo 5b y 5c) se comenta a continuación, porque permite analizar fórmulas de culto a los ancestros que pudieron traer consigo las primeras generaciones de inmigrantes itálicos que se asentaron en el sur de la península ibérica y de qué

\footnotetext{
${ }^{31}$ Se conoce, al menos, una excepción, la tumba $\mathrm{n}^{\mathrm{o}} 372$ (Paris et al. 1926: 73) en la que el "galet" funerario se colocó entre el plinto y la mesa de libaciones, y no en contacto con la fachada de la cupa propiamente dicha, aunque si la hipótesis de G. Bonsor sobre el proceso de construcción del monumento fuese correcta (la mensa se situó con posterioridad a la finalización de éste), podría explicarse por esta razón la peculiar posición del 'muñeco'.
} 

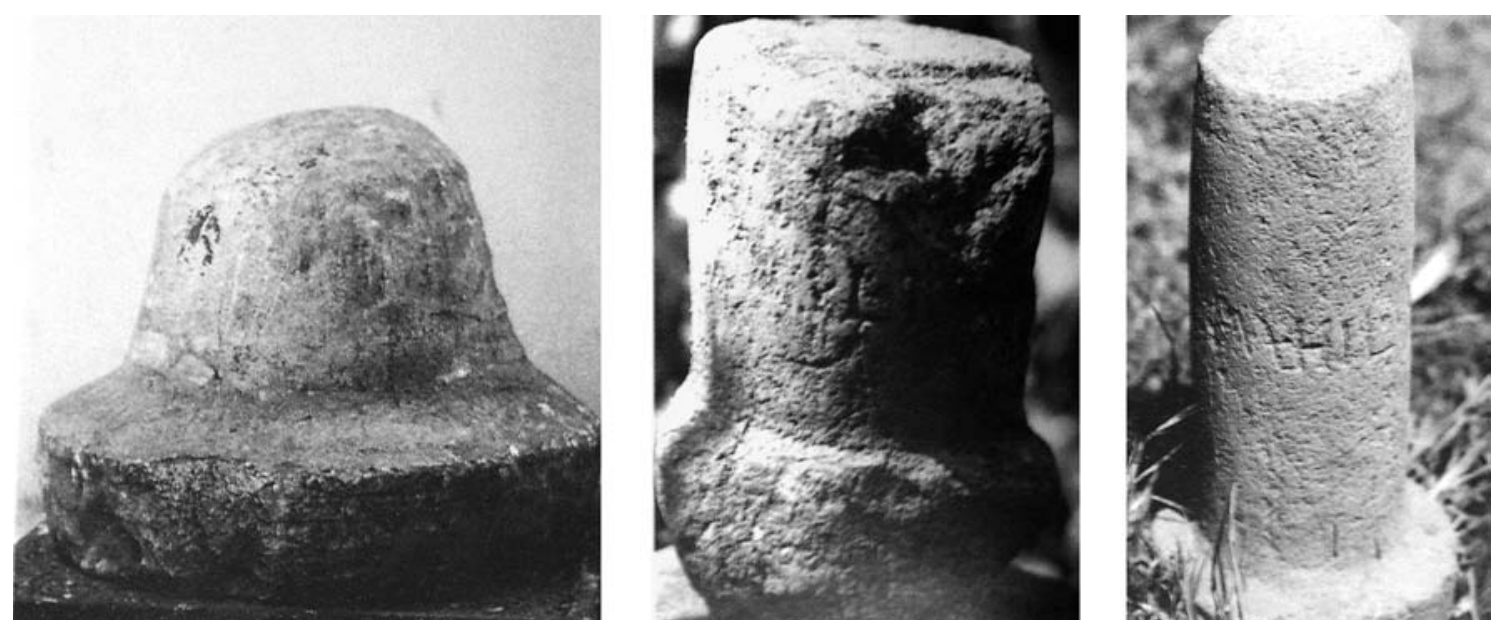

Figura 11. Cipos funerarios etruscos de distintos tipos procedentes de Caere (según Blumhofer, 1993: taf. 16).

forma pudieron ser transformadas, con el paso del tiempo, en Baelo Claudia.

En diversos yacimientos italianos se han hallado conjuntos importantes de cipos funerarios similares a los hallados en las necrópolis de Bolonia, que habían sido situados tanto en el interior como exterior de las tumbas, junto a una de las fachadas, coronando el túmulo de tierra de algunos monumentos, o incluso en pequeñas oquedades creadas a tal efecto dentro de las construcciones, desde época arcaica hasta finales de la República. Son por tanto piezas que comparten con los cipos de Baelo su carácter liminal, y que incluso en ocasiones se situaban en los lindes de los terrenos o en los cruces de caminos para señalar un límite (Blumhofer, 1993: 153). Algunas piezas presentan inscripciones con el nombre de difunto, e incluso se han documentado casos (cipo en forma de clava de la necrópolis de la vía de Gello en Pisa, s. III a. C.) donde el pronombre personal y el nombre aparecen en nominativo y el verbo en primera persona, lo que ha llevado a sugerir que estos cipos podían considerarse como una imagen que sustituía al difunto o como un "doble" del mismo (Paribene, 1999: 14). Pero uno de los aspectos más interesantes es que, tanto en las necrópolis italianas como en el yacimiento gaditano, los cipos antropomorfos y anicónicos conviven durante un período importante de tiempo. A partir de época tardo-helenística, empiezan a aparecer un conjunto de cipos que presentan cierta tendencia a la 'antropomorfización' de la parte superior de la pieza, que suele engrosarse para acoger los rasgos de un rostro, para simular la presencia de una corona vegetal o para asemejarse a un busto. Sin embargo, y esto debe tenerse especialmente en cuenta a la hora de interpretar los materiales hallados en Baelo Claudia como objetos con cierto aire 'arcaizante', la perduración de esta clase de tallas en época imperial es francamente excepcional en la península italiana.

Un conjunto destacado de estas piezas procede de la necrópolis de época tardorrepublicana de Cerveteri (la antigua Caere, ss. IV-I a. C.; Mengarelli, 1915; Blumhofer, 1993; Pensabene, 1977: 428) (fig. 11). En concreto, en el sepolcreto della Banditaccia, se encontraron, a principios de siglo XX, en un área que había sido arrasada en el siglo IV a. C. para construir de nueva planta un conjunto de cámaras funerarias de acuerdo con un plano ortogonal, un grupo de cipos que respondían a tres tipos básicos. Por un lado estaban aquéllos en forma de columna con basa circular o cuadrangular; por otro, el grupo formado por cipos semejantes a pequeñas casas o sarcófagos y, finalmente, un tercer conjunto compuesto por piedras lisas redondeadas. En ocasiones los cipos estiliformes presentaban la parte superior engrosada en forma de cabeza humana. Estas piezas se colocaban mayoritariamente a la entrada de las cámaras funerarias, sobre grandes lastras de piedra que presentaban una serie de oquedades destinadas, precisamente, a instalar cada uno de los cipos (fig. 19). Muchas de ellas, al igual que los ejemplos procedentes de la Campania ya mencionados, presentaban una inscripción con el nombre del difunto en lengua etrusca o latina. La mayoría de las leyendas habían sido grabadas en la piedra, aunque al menos en un caso se documentó un epígrafe realizado con ocre de color rojo.

En la necrópolis etrusco-romana de Tarquinia, en uso al menos hasta el s. I a. C., también se han descrito piezas similares, nuevamente situadas tanto en el interior como en el exterior de las cámaras sepulcrales (fig. 13). El tipo más común es el de la columna troncocónica sobre basa, que suele ser el lugar ocupado por el epígrafe funerario en contraste con los cipos de Caere, donde tanto el fuste de la columna como la basa podían aparecer inscritos. En Tarquinia los cipos oikomorfos - 

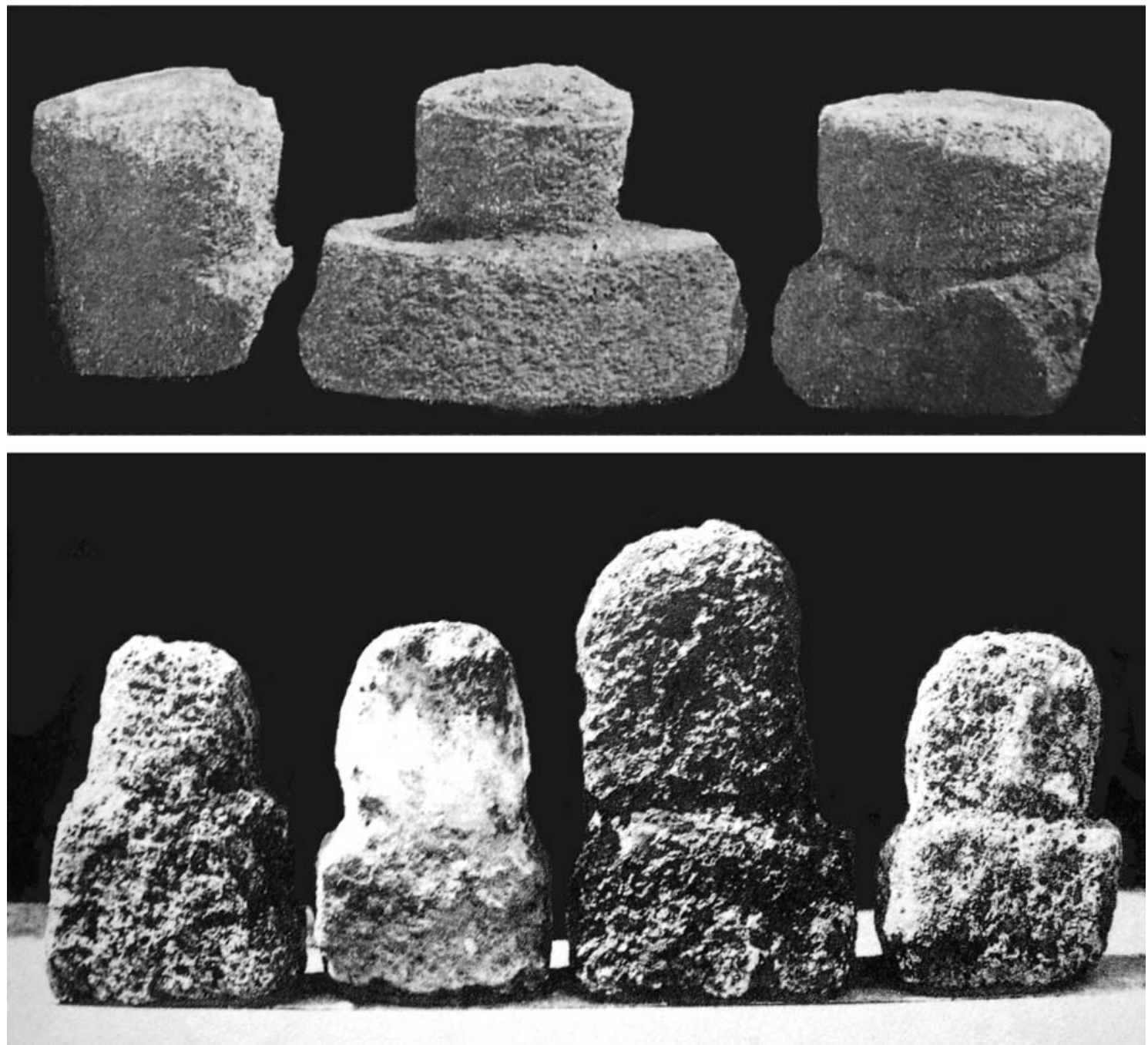

Figura 12. Cipos anicónicos de Bolonia (según Mergelina, 1927: fig. 26 y Paris et al. 1926: pl. XIX).

que no han sido encontrados en Bolonia- están prácticamente ausentes, pero, en cambio, se encontraron algunos ejemplares en los que se había grabado someramente los rasgos de una cara sobre la parte superior del remate troncocónico.

Los cipos estiliformes (con basas cuadrangulares o circulares) y de forma troncopiramidal sobre basa cuadrada están presentes también en otros yacimientos etruscos, como Marzabotto, Chiusi, Saturnia, Tuscania, Norchia, Orvieto o Castel d'Asso y algunos otros de la zona de Volterra o la Versilla (Blumhofer, 1993; Bizzarri, 1962; Bonamici, 1991; Colonna di Paolo, Colonna, 1970; Cristofani, 1973; Rosi, 1927; Paribene, 1999; Steingräber, 1991; Steingräber, 2002: 137).

Existen algunas diferencias entre el conjunto de cipos anicónicos procedente de Baelo Claudia (fig. 12) y los materiales hallados en Etruria. Por ejemplo, no se han encontrado aún en Baelo Claudia cipos oikomorfos,

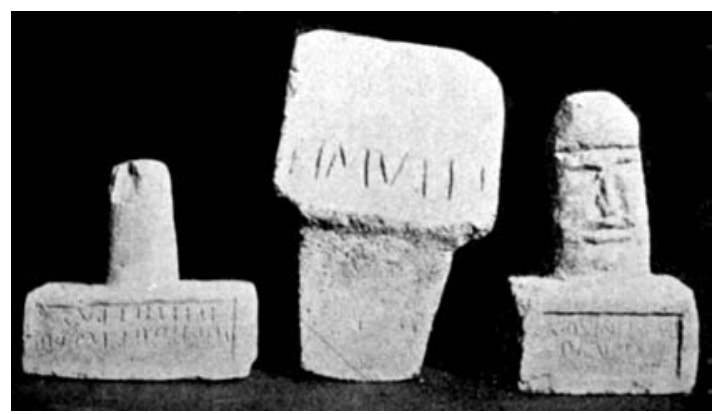

Figura 13. Cipos funerarios de la necrópolis de Tarquinia (según Pallotino, 1937, fig. 98). 

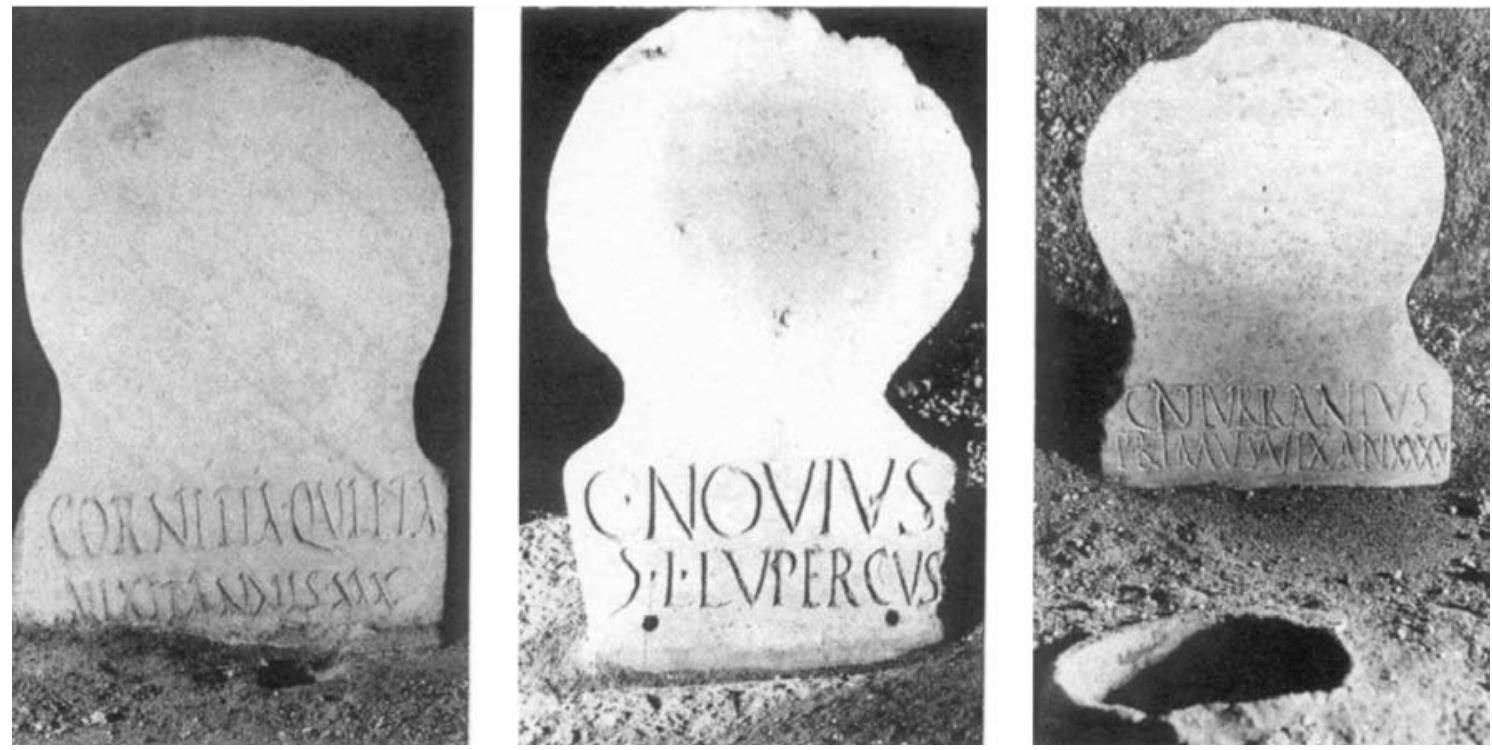

Figura 14. Pompeya, Necrópolis de Porta Nocera. Columelle de la tumba E Norte. (según D’Ambrosio y Caro, 1987: Taf. 33 a-c).

ni en forma de altar, bulbo, seta, cono u obelisco, que sí están presentes en ciertas necrópolis de la península italiana (Steingräber, 1991: 1081-1082), si bien, evidentemente, no en todos los yacimientos italianos se pueden encontrar ejemplos de todas las clases de cipos. Por otro lado, los cipos funerarios de Belo son anepígrafos, a no ser que pensemos en inscripciones realizadas con ocre $u$ otros pigmentos similares y perdidas por el paso del tiempo. Además, teniendo en cuenta su posición respecto al suelo de uso, resulta difícil pensar en la existencia de leyendas pintadas para ser vistas sobre la basa o el fuste de estas piezas. Otro elemento a destacar es la cronología republicana de los ejemplos italianos -aunque hay piezas que se sitúan excepcionalmente en época augustea (Paribeni, 1999: 14 y nota 7), que contrasta con la datación en el s. I d. C. del conjunto de Bolonia. Allí donde ha sido posible aquilatar la cronología con mayor precisión dentro del yacimiento hispano se ha señalado el inicio del uso del espacio sepulcral -al menos- desde época de Tiberio (Remesal, 1979), si bien durante las excavaciones en la necrópolis oriental de principios de siglo se encontraron monedas de época tardorrepublicana. No obstante, un habitante de la península italiana que llegase a Bolonia a principios del s. I d. C. podría percibir, muy probablemente, un uso consciente de cierto lenguaje 'arcaizante' en el empleo de este tipo de tallas, aspecto especialmente patente en tipos como el de la columna truncada sobre basa circular, que tiene sus orígenes en las necrópolis etruscas en la segunda mitad del s. IV, aunque se mantuvo en uso hasta el s. I a. C. y que sólo en contadas ocasiones ha podido constatarse en época altoimperial (Blumhofer, 1993: anexo 1a).
Precisamente en época imperial este tipo de piezas sufren una transformación esencial en la península italiana que, al parecer, no se produce en los cipos de Baelo Claudia. En Italia, los cipos con busto terminal evolucionan hasta convertirse en verdaderos bustos que pasan a situarse en los nichos de los columbarios o en el interior de recintos funerarios. Estas piezas terminan por ser sustituidas, en la mayoría de los casos, por estelas individuales o monumentos con relieves funerarios que tienen, como función fundamental, señalar la localización del enterramiento. Los cipos de carácter anicónico, sobre todo aquellos estiliformes, tienden, por el contrario, a desaparecer (Pensabene, 1977: 429).

Sin embargo, hay un conjunto de estelas de carácter muy particular, denominadas en la bibliografía italiana columelle, que D. Vaquerizo (2002: 181; 2006: 352) ha sugerido relacionar con los cipos hallados en las necrópolis de Baelo Claudia, puesto que, de alguna manera, recogen la idea de mezclar en un mismo monumento funerario rasgos anicónicos y antropomorfos (fig. 14). Se trata de un conjunto de estelas talladas en piedras calcáreas, volcánicas o en mármol, con la parte superior redondeada y fuste estrecho de tendencia alargada, que parecen ser una abstracción de un busto humano. Son escasísimos los ejemplos en los que se representan los rasgos fisonómicos del difunto en la zona del campo epigráfico que correspondería al rostro ${ }^{32}$. Lo más común es que la parte frontal esté vacía o recoja una inscripción con el nombre de la

\footnotetext{
32 Se han contabilizado algunos casos en Pompeya y otro recientemente en la antigua Nuceria (De'Spagnolis, 2001: 176).
} 

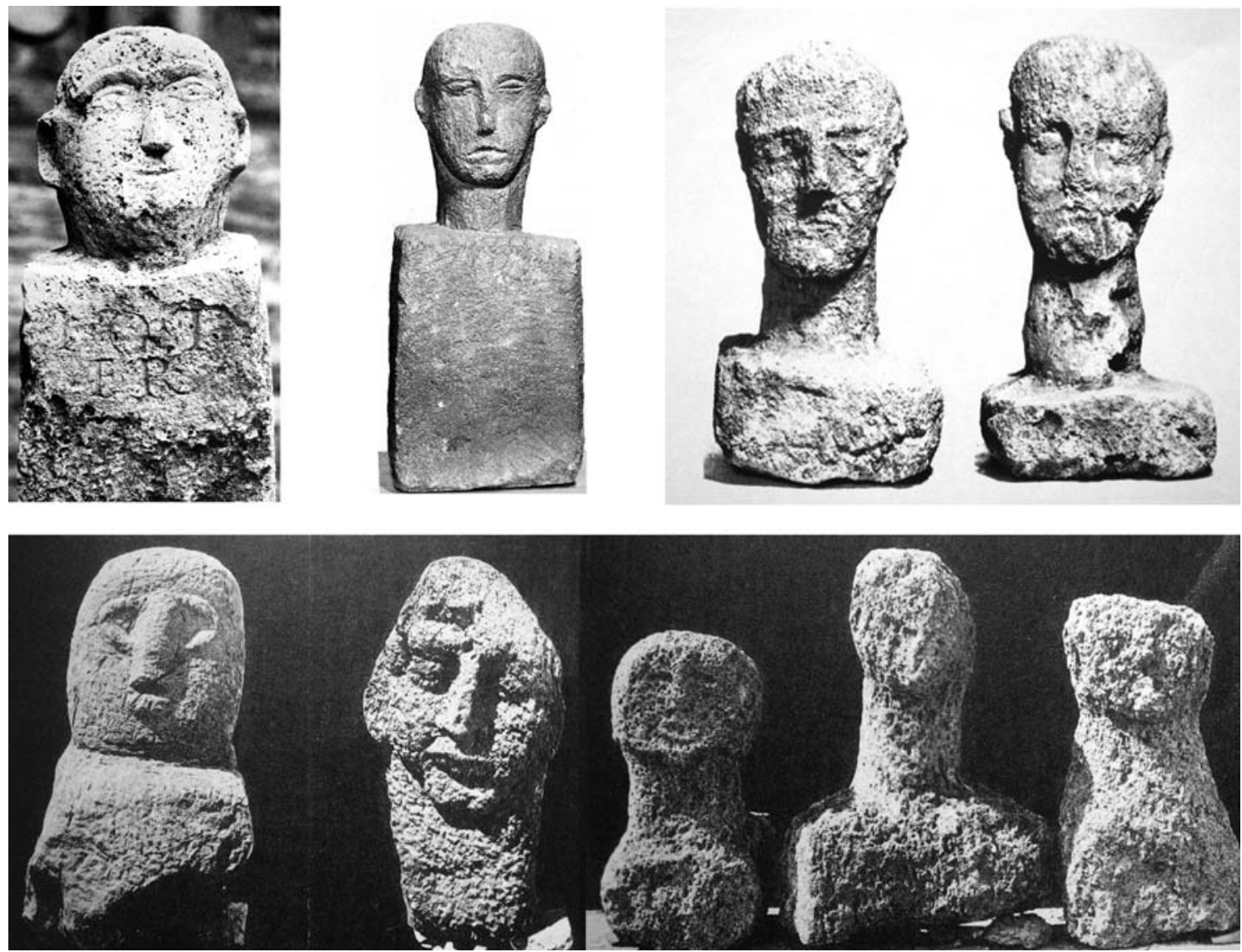

Figura 15. Cipos funerarios de Tarento (A partir de P. Pensabene, 1975, Taf. 99, 88 y 89) (arriba). Baelo Claudia. Necrópolis oriental. Cipos de carácter antropomorfo (tomada de Paris et al. 1926: pl. XVI y XVIII) (abajo).

persona conmemorada -aunque algunas son anepígrafas-, mientras que la posterior puede presentar también una superficie lisa, en el caso de lápidas dedicadas a varones, o estar tallada imitando el cabello, a veces trenzado, en el caso de las estelas que conmemoran mujeres. El ámbito geográfico donde han sido halladas estas piezas es también muy reducido. Se concentran fundamentalmente en la Campania, en el territorio de la antigua confederación nocerina, en yacimientos como Pompeya, Stabia, Sorrento, Herculano o Sarno, donde están fechadas entre finales del s. II a. C. y la segunda mitad del s. I d. C. (De'Spagnolis, 2001: 177; D’Ambrosio, De Caro, Vlad Borelli, 1983; Kockel, 1987; D’Ambrosio, De Caro, 1987). A la hora de identificar las piezas de Belo con las columelle de la Campania se plantean las mismas dificultades que ya observamos al buscar una relación con las estelas del mundo púnico: los cipos funerarios de Bolonia no responden al modelo de estela epigráfica de forma paralepípeda destinada señalar un enterramiento individual, y por lo tanto, en mi opinión, existen dificultades para asimilarlos ritualmente a las columelle de la Campania.
No obstante, la relación entre los cipos de carácter antropomorfo y los bustos funerarios que empiezan a ser especialmente comunes a partir de época altoimperial, debe estudiarse con mayor profundidad. En algunos de los cementerios en las que están presentes las columelle, como en Tarento o la necrópolis de Porta Nocera en Pompeya, se ha hallado también otra serie de representaciones que podrían ponerse en relación con nuestro problema, sobre todo porque en esta ocasión nos encontramos, no ante estelas epigráficas de silueta más o menos antropomorfa pero sin rostro, sino ante verdaderos bustos funerarios que presentan en ocasiones sorprendentes similitudes tipológicas con algunos ejemplares de Belo ${ }^{33}$. Dos de ellos fueron halladas en los nichos de un monumento a Fornix de Porta Nocera (D'Ambrosio, De Caro, Vlad Borelli, 1983: 7-OS), pero quizá el

33 Que no pasaron desapercibidas, ya en los años cincuenta, a A. García y Bellido (García y Bellido, 1955: 92) y que ha vuelto a señalar recientemente P. Rodríguez Oliva (2002: 279). 
grupo más numeroso procede de Tarento, aunque, lamentablemente, la mayoría carece de contexto arqueológico. Fechados entre el s. I a. C. y época altoimperial, difieren claramente de las costumbres funerarias y de los cipos empleados en las necrópolis "griegas" del asentamiento de los siglos anteriores, por lo que se ha querido relacionar su aparición con la influencia de nuevos colonos presentes en la ciudad. Las tumbas de época romana solían estar indicadas en superficie con una estela, por lo general muy sobria, con el nombre del difunto, la edad en la que le sorprendió la muerte y la fórmula H.S.E., aunque a veces estas lápidas habían sido sustituidas por un pilastrino, que sostenía un "busto" ${ }^{34}$ que no siempre se puede considerar un retrato. P. Pensabene (1975: 276) recoge los detalles del hallazgo de una de estas piezas recuperada el 30 de mayo de 1936 en Vía Dante. Como en Baelo, curiosamente, al menos en este caso, no existió una relación directa entre la cantidad de individuos enterrados y el número de cipos antropomorfos colocados sobre la tumba, pues la pieza hallada en Vía Dante se superponía a tres urnas cinerarias ${ }^{35}$ (Pensabene, 1975: 276, nota 79). En concreto, en el Museo de Tarento, se conservan dos ejemplares de este grupo de cipos que recuerdan de cerca a los tipos Baelonenses, con basa circular, fuste y rostro o basa cuadrangular y rostro. Muchos otros se prolongan por debajo del cuello y poseen un remate convexo que se asemeja a todo un conjunto de representaciones de bustos de los difuntos, abundantes especialmente en relieves funerarios, y que están relacionados con un complejo debate sobre los modos de representación de los ancestros en el mundo romano que debemos abordar brevemente si queremos analizar el posible significado de los cipos funerarios encontrados en Baelo Claudia (fig. 15).

\section{LA CASA Y EL SANTUARIO: CULTO A LOS ANCESTROS EN CONTEXTOS NO FUNERARIOS}

¿Qué función ritual desempeñaron estas piezas? ¿Cuál fue su significado? Tanto R. Mengarelli (1915)

\footnotetext{
${ }^{34}$ En palabras de R. Bartoccini, que excavó algunas de estas tumbas "Ma che coraggio ci vuole a chiamarli busti! Sentendo questa parola si pensa subito a ritratti, e ci si imagina che in qualche modo dovessero rassomigliare al difunto o alla defunta. Quale disinganno! Non ho mai visto una più desastrosa raccolta di brutte facce." (R. Bartoccini, Taranto, Rassegna del Comune 12, 1934, p.3, citado por Pensabene 1975: 276).

35 Una urna cuadrangular de piedra con los huesos calcinados y un espejo de bronce; una urna cerámica con restos óseos y un ungüentario de vidrio; y una tercera similar a la anterior con una pequeña píxide en hueso, un ungüentario de vidrio y lo que podrían ser dos ungüentarios cerámicos de época augustea.
}

como M. Pallotino (1937) defendieron, a principios del s. XX, que los cipos de Caere y Tarquinia eran "il segno della deposizione individuale" (Pallottino, 1937: 394). De forma semejante se ha expresado M. Blumhofer (1993: 153, 160), que interpreta estas piedras como semata de los difuntos, si bien subraya que nos encontramos ante objetos de carácter sacro y que su función iba mucho más allá de señalar simplemente una tumba. En la misma línea argumental P. Pensabene (1977: 427, 430) defiende la idea de que no es posible excluir del todo el significado de sustituto del muerto, como sede del alma, lo que explicaría la evolución hacia tipos antropomorfos del sema. Cómo "símbolos del muerto" interpretó en su día A. García y Bellido (1955: 92) los cipos de Belo a pesar del carácter casi genérico del rostro de muchos ejemplares, que les alejan de una representación fiel de los rasgos del difunto, o la propia ubicación en un lugar poco apropiado para la exhibición de un retrato.

Es posible que no nos hallemos ante la representación de "ancestros" individuales, con rostro y nombre, pero sí ante un tipo de objeto ritual -un "colossos", un doble- que permite conjurar a los antepasados entendidos como un grupo indiferenciado.

Las imagines de los ancestros adoptaron formas diversas en el mundo latino. Una imago podía ser la máscara de cera de un ancestro que había desempeñado un cargo público que se guardaba en el atrio, pero también un reflejo en un espejo, o el eco, entendido como el reflejo de un sonido, una aparición ilusoria, un fantasma, un duplicado, copia, imitación o aquello que recuerda -pero no es- alguna cosa; una imago es lo que señala o hace visible, un ejemplo, manifestación o personificación; es también una forma visible, figura o representación artística de una persona u objeto (Glare, 1968b). Es decir, es una imagen que simula la apariencia de algo que no está presente o es invisible: es la imagen que da forma a lo incorpóreo.

El propio Plinio señala que en sus días había distintas maneras de representar a los ancestros en la casa y que todas ellas eran consideradas imagines. En primer lugar se mencionan las máscaras conservadas en el armario del atrio, pero también otra clase de representaciones como retratos pintados (imagines pictae) -a veces como una representación de las distintas ramas familiares en forma de corona o guirnalda (stemmata)- (Bettini, 1988: 169 y ss.; Id., 1992: 260), retratos en escudos (imagines clipeatae) ${ }^{36} \mathrm{y}$ otras imagines (alia imagines)

\footnotetext{
${ }^{36}$ En ocasiones se hacían copias directas de retratos de ancestros de contextos domésticos que eran colocadas en edificios públicos, como los retratos en escudos encontrados en algunos templos. En cualquier caso, este tipo de imagines pueden relacionarse, según D. E. E. Kleiner (1977: 87) con todo un conjunto de retratos en tondi tallados en relieves funerarios, aunque también aparecen en pinturas.
} 

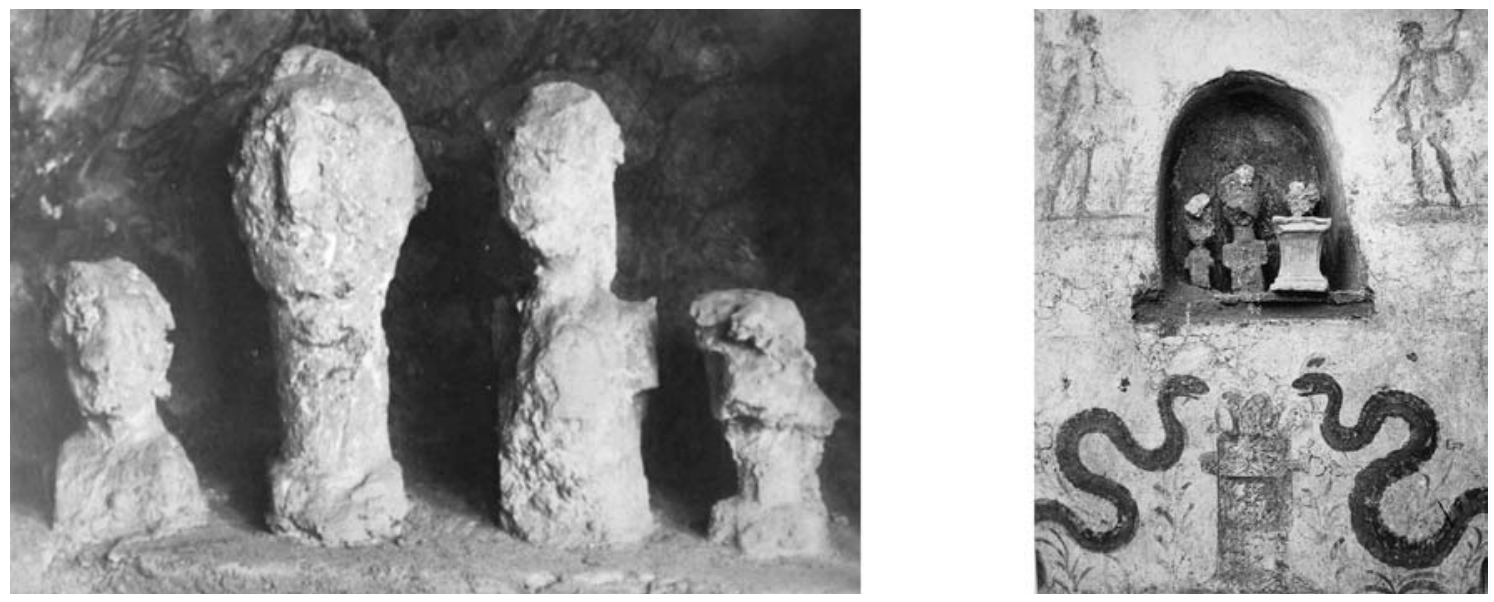

Figura 16. Figurillas halladas en la exedra 25 de la "Casa del Menandro" (izquierda) y en la "Casa di Balbo" (derecha) ambas en Pompeya (Según Fröhlich, 1991: Taf. 25.3).

relacionadas con ancestros especialmente famosos, que habían obtenido un triumphus en vida ${ }^{37}$.

Pero además de estos antepasados que conservaban intacta su identidad individual existían imágenes para los ancestros entendidos de manera 'genérica' como 'entes indiferenciados', que se colocaban en los lararios. En los catálogos de lararia de ciudades como Pompeya o Herculano se recogen numerosas representaciones de los Lares, que aparecen como jóvenes vestidos con túnica corta que sujetan una pátera o escudilla y un vaso en forma de cuerno (rhyton) siguiendo modas de carácter helenístico como otras representaciones pictóricas clasificables dentro de los distintos estilos pompeyanos (Orr, 1988: 296). En alguna ocasión se han encontrado figurillas de bronce aún in situ

\footnotetext{
${ }^{37}$ Sin embargo, incluso estas fórmulas esteriotipadas de representar a antepasados concretos en contextos domésticos terminan 'contaminando' de alguna manera las representaciones de antepasados que se situaban sobre las tumbas. La representación de bustos de los difuntos es muy frecuente en esculturas de bulto redondo o en relieves funerarios, especialmente entre aquellos que conmemoraban a libertos, mujeres y niños de época tardorrepublicana o altoimperial (Kleiner, 1977: 188-189). Ninguno de estos grupos sociales habría tenido la opción de detentar un cargo público, una condición imprescindible para ser representado con una máscara ancestral en el armario del atrium familiar. Los esclavos quedaban bajo la tutela de su señor -perdían el lazo de unión con sus padres- cuando entraban a su servicio y si alcanzaban la condición de libertos adoptaban el nombre de su patrón y no de sus ancestros. No obstante, por medio de la apropiación del lenguaje simbólico empleado en el atrio por las élites y a través de la recreación de una serie de elementos tradicionales combinados de una manera original, los libertos pudieron enfatizar su recién obtenido estatus de hombres libres, y, posiblemente de manera aún más importante, el derecho recién adquirido a convertirse en 'ancestros' para las generaciones venideras.
}

en el altar doméstico que siguen estos modelos iconograficos. Pero a veces este tipo de imágenes de los Lares podían compartir el espacio sagrado del altar doméstico con representaciones de un aspecto bien distinto. Uno de los mejores ejemplos procede de la 'Casa del Menandro' ${ }^{38}$, en Pompeya, aunque se hallaron piezas similares en la 'Casa di Balbo' ${ }^{39}$ (fig. 16), también en Pompeya, y otras que permanecen inéditas en Herculano (Flower, 1996; Maiuri, 1932: 102; Foss, 1997: 199; Fröhlich, 1991: 254). En el momento de la erupción de 79 d. C. en uno de los altares del peristilo de la 'Casa del Menandro' situado en la exedra 25, se encontraban cinco figurillas, probablemente esculpidas en madera ${ }^{40}$, que dejaron sus improntas en las cenizas volcánicas ${ }^{41}$. Los moldes de yeso realizados

\footnotetext{
${ }^{38}$ Casa Grande I.10.4.

39 También conocida como 'Casa Piccola'-I.8.18. En el larario de la 'Casa di Balbo' se repite el esquema de la ubicación de dos burdas figurillas en un nicho rodeado de pinturas con decoraciones 'helenísticas'. En este caso en los frescos se representó a los Lares según la costumbre griega, como dos hermosos jóvenes junto a dos serpientes (animal normalmente asimilado al genius aunque comparte ciertos elementos con el agathos daimon griego) afrontadas a un altar (Foss, 1997: 199).

${ }^{40}$ Tibulo, por ejemplo, aseguraba que sus lares habían sido tallados en madera (Orr 1978: 1566).

${ }^{41}$ Ya A. Maiuri llamó la atención sobre la singular 'tosquedad' de las estatuillas, que, de acuerdo con su opinión, no podía ser atribuida al proceso por el cual se había obtenido el molde de dichas figuras: "Colpisce subito la singolare rotezza di queste sculture, che non è da imputare nè al procedimento del calco in gesso nè ad impurità degli strati, ma alla modellatura stessa dei pezzi ed al loro statu di conservazione al momento dell'eruzione; di uno solo di essi, l'ultimo a destra, el calco non ha reso che una parte della forma plastica originaria" (Maiuri, 1932: 100).
} 
en el momento de la excavación nos han permitido conocer aproximadamente su aspecto original. Lo más interesante del caso es que una de ellas (la situada más a la izquierda) era una representación de un joven desnudo portando una guirnalda, que ha sido identificado, siguiendo la costumbre, con el Lar domesticus. Pero las cuatro restantes, que A. Maiuri (1932: 104) en los años treinta interpretó como representaciones de los Manes o imagines maiorum, consistían en cuatro bustos de tamaño algo menor que el natural, de carácter deliberadamente arcaico que contrastaban con la sofisticada decoración de estilo helenístico de las paredes de la casa (Orr, 1978: 1582; Wallance-Hadril, 1988: 88; Flower, 1996: 42, Maiuri, 1932: 96-106) у que recuerdan a los cipos funerarios de carácter más antropomorfo de Belo.

Los altares dedicados a los Lares no se situaban en el atrio, donde generalmente se exponían las máscaras de los ancestros famosos, con rostro y nombre, de las familias aristocráticas, sino cerca de la cocina o en relación visual directa con ella, como sucede en viviendas de mayor tamaño como la 'Casa del Menandro', por la estrecha relación que existía entre los Lares y el fuego sagrado del hogar que cocinaba el alimento de toda la familia (Foss, 1997). Ésta era, además, la llama asociada a Vesta. Su proximidad al hogar y el carácter intencionadamente anticuado de estas figurillas podría explicar por qué ciertas imagines son descritas en las fuentes antiguas como objetos ennegrecidos por el humo, antiguos y arcaicos (fumosus, vetus, priscus) (Flower, 1996: 34)

Las imágenes que se colocaban en los altares domésticos estaban relacionadas con el culto a toda una serie de numina de carácter ancestral -Vesta, los Lares y los Penates- que vigilaban el bienestar y la nutrición de la familia y por lo tanto, en último extremo, 'garantizaban' la sucesión entre generaciones.

Los Lares, como los Manes a los que se alude en las inscripciones funerarias, pertenecen a ese conjunto de divinidades de carácter 'indiferenciado' a las que los romanos se referían en plural ${ }^{42}$ (Harmon, 1978: 1593). Eran también los dioses de los límites, a los que se brindaban ofrendas en altares situados en el compitum o punto en el que se producía la intersección de los lindes de cuatro caminos o cuatro propiedades, un lugar considerado especialmente peligroso, inestable y cargado de numina. Pero los Lares también jugaban un papel importante en los rituales de carácter liminal -de cambio de estado, en los que se traspasaba de forma simbólica algún 'límite'- que tenían lugar a lo largo de

${ }^{42}$ Se empleaba, sin embargo, una fórmula singular para referirse al Lar familiaris. la vida de una persona. Por ejemplo, los niños depositaban en el larario familiar la bulla, el amuleto que les había acompañado durante toda la infancia, el día que tomaban la toga virilis, mientras que a las niñas les entregaban, entre otros objetos, una muñeca o una moneda el día de su boda ${ }^{43}$ (Harmon, 1978: 1595, 1598; Pera, 1993: 350). Merece la pena destacar la corriente aparición de algunos de estos objetos, especialmente monedas, muñecas o bullae, en tumbas infantiles de época romana. Quizá estos objetos, que no habían sido consagrados a los Lares en el altar doméstico por culpa del destino, se dedicaban de alguna manera a 'sus equivalentes': los dioses del inframundo.

La idea de que los Lares eran una especie de ancestros deificados a los que se rendía culto en la domus puede entreverse también en diversos textos griegos donde el término Lar aparece utilizado como un equivalente de heros (Orr, 1978: 1564, nota 31) o en un pasaje de Plinio (H. N. 28, 27-28), en el que se nos explica que aquel pedacito de comida que caía al suelo durante el banquete debía ser quemado frente al altar de los Lares, porque el suelo es el hogar de los fantasmas y los alimentos que en él caen deben consagrarse a los dioses del inframundo. También Festo se refiere a ellos como dioses inferorum cuando describe el ritual que tenía lugar en los altares dedicados a los Lares en los cruces de los caminos durante los compitalia $^{44}$. Después de un banquete en el que cada familia ofrecía un pastel de miel a los dioses tenía lugar una interesante ceremonia de 'sustitución' de los miembros de la familia por un simulacrum. Cada miembro libre de la casa era representado por una efigie masculina o femenina de lana y cada esclavo por una pelota que debían colgarse del altar dedicado a los Lares (Orr 1978: 1566; Harmon, 1978: 1595; Ramos Crespo, 1988)

Se puede decir que todos estos dobles y simulacra actuaron de alguna manera como intermediarios entre dos niveles de la realidad, aquel del mundo de los vivos y el del reino de los muertos, haciendo visible lo que ha sido mantenido fuera de la mirada de los hombres. La imagen de piedra, cera o madera puede actuar como un 'contenedor temporal' para las sombras (que pueden ser los Manes o los muertos que han

\footnotetext{
${ }^{43}$ Schol. Cruq. ad Hor. Sat. 1.5.69, Varro en Non. 863.15L.

44 Paulus ex Fest.. 273L 2; cf. Paulus ex Fest 108L²: Pilae et effigies viriles et mulibres ex lana conpitalibus suspendebantur in conpitis, quod hunc diem festum esse deorum inferorum, quos vocat Lares, putarent, quibus tot pilae, quot capita servorum; tot effigies, quot essent liberi, ponebantur, ut vivis parcerent et essent his pilis et simulacris contenti.
} 
perdido la memoria individual al ser integrados en la comunidad de los antepasados) cuando se requiere su presencia para que puedan beneficiarse de las libaciones que se les ofrecen, o para fijar a las 'almas' intranquilas y obligarlas a que permanezcan en el 'más allá'.

El culto a los ancestros que tenía lugar en la tumba pertenece, por lo tanto, a un sistema ritual mucho más amplio y complejo, con ceremonias asociadas a los antepasados individuales, familiares y colectivos en escenarios tan importantes como los altares domésticos, los santuarios o los templos cívicos. De hecho, en depósitos votivos de distintos santuarios de la península italiana han sido halladas un conjunto de piezas de terracota que reproducen la morfología de algunos de los cipos pétreos hallados en las necrópolis etruscas (Pensabene, 1977: 430, Blumhofer, 1993: 153; Gatti lo Guzzo, 1978: 142, tav. LIII, U, 8 y U,14; Pensabene et al. 1980: 321-322, Tav. 113; Vagnetti, 1971: 103, Tav. LVIII, 1-4; Antonelli, 1927: 233-235, fig. 13, no 9-15; Comella, 1978: 82-86, Tav. XXXVII, XXXVIII). En dichos contextos sacros, las terracotas cónicas, en forma de bulbo o piña, convivían con pequeñas estatuillas de terracota que, no lo olvidemos, se introducen a menudo también como ofrenda en las tumbas. Algunas reproducen la imagen de la divinidad, otras son máscaras, figurillas de ciertos animales o distintas partes del cuerpo, pero tampoco es infrecuente encontrar "cabezas" -bustos de terracota- de rasgos estereotipados.

Si admitimos que los cipos funerarios de Baelo Claudia no son simples estelas, independientemente de que la forma de los ejemplares anicónicos pueda asemejarse a determinados tipos de semata presentes en necrópolis púnicas ${ }^{45}$, y que pertenecen a una esfera ritual relacionada con el culto a los antepasados que desborda el ámbito exclusivamente funerario, resulta aún más significativo el hecho de que algunos de los mejores paralelos formales del sur peninsular hayan sido encontrados en contextos rituales que no siempre se pueden relacionar con seguridad con espacios de enterramiento. Algunas de las tallas halladas en Torreparedones, de bulto redondo, de tipo estiliforme o directamente asimilable a la forma de algunos cipos betílicos púnicos, también tuvieron un carácter esencialmente votivo y presentan algunos puntos de conexión con los materiales de Baelo (Seco, 1999: 139; Cunliffe, Fernández Castro, 1999: 321-397). Entre los restos de una casa de tipo pompeyano de Córdoba fue recuperada una columnilla en cuya basa se había tallado la palabra GENIVs (Rodríguez Oliva, 1994: 10), lo que permite comprobar la existencia de cierta asocia-

\footnotetext{
45 Ver nota 17.
}

ción de esta clase de divinidades con representaciones anicónicas en época romana.

Éste es también el caso de un cipo estiliforme, un huevo de piedra oscura y una piedra tallada de forma triangular, con un ligero rebaje en la parte inferior de una de las caras y huellas de la acción del fuego sobre la base ${ }^{46}$, hallados recientemente en Carmona (fig. 17). Estos objetos habían sido amortizados en el interior de un pozo junto a distintos elementos (cuencos y platos de barniz negro, campaniense B tipo Cales, Terra Sigillata Itálica y cerámica de tipo Peñaflor, vasos de paredes finas, lucernas, cerámica de tradición indígena, ollas, tapaderas, ánforas, ungüentarios, discos recortados de distintos tipos de piezas cerámicas, pesas de telar y una pesa de plomo, un as con la efigie de Jano y un as de Carmona), que pueden situarse cronológicamente en torno al cambio de era (Belén, Lineros, 2001: 130; Belén, Conlin, Anglada, 2001). Hay que recordar que el pozo de Carmona se encontraba situado a extramuros, como las necrópolis de época romana, en conexión, de acuerdo con estos autores, con un complejo termal. No deja de ser interesante que algunas de estas piezas de aspecto betiliforme hallan sido recuperadas en pozos o vinculadas de alguna forma con las aguas -es decir en puntos limítrofes y de conexión con el inframundo, al igual que las tumbas-. La piedra de forma ovoidea localizada en la famosa "tumba" del elefante de la necrópolis de Carmona -otro espacio donde lo sacro y lo funerario se encuentran íntimamente entrelazados-, pudo muy probablemente haber sido encontrada por los excavadores en el fondo de un pozo, como efectivamente lo fue la propia escultura del animal (Bendala, 1976: 58). R. Corzo (1991: 402) halló en el santuario de la Algaida (Sanlúcar de Barrameda, Cádiz) "en la zona más próxima al antiguo cauce del Guadalquivir (...) una pequeña estructura de protección de un pozo, y junto a éste había un fuste liso de piedra arenisca y un capitel dórico del mismo material, que deben atri-

\footnotetext{
${ }^{46}$ El cipo estiliforme, de $75 \mathrm{~cm}$ de altura y $18 \mathrm{~cm}$ de diámetro, sobrepasa en altura los ejemplares de mayor tamaño de Baelo que alcanzaban algo más de $60 \mathrm{~cm}$ de altura (MAN 33 183 26/15/990). Quizá sea posible relacionar la piedra de alcor tallada en forma triangular $(22 \times 15 \times 5 \mathrm{~cm})$ con materiales similares procedentes de las necrópolis de Cádiz o Villaricos, o con la ya mencionada piedra tallada de la tumba XVIII de la necrópolis sureste (fig. 4, derecha). M. Belén, E. Conlin y R. Anglada sugieren como hipótesis una posible relación de estas piezas con cultos en honor a Adonis, si bien los mismos autores señalan que "Estelas y cipos funerarios, que son mucho más que simples indicadores de la ubicación de las tumbas, se labran con la misma forma, o bien como inequívocas columnas con fuste y capitel." (Belén, Conlin, Anglada, 2001: 149, 151).
} 


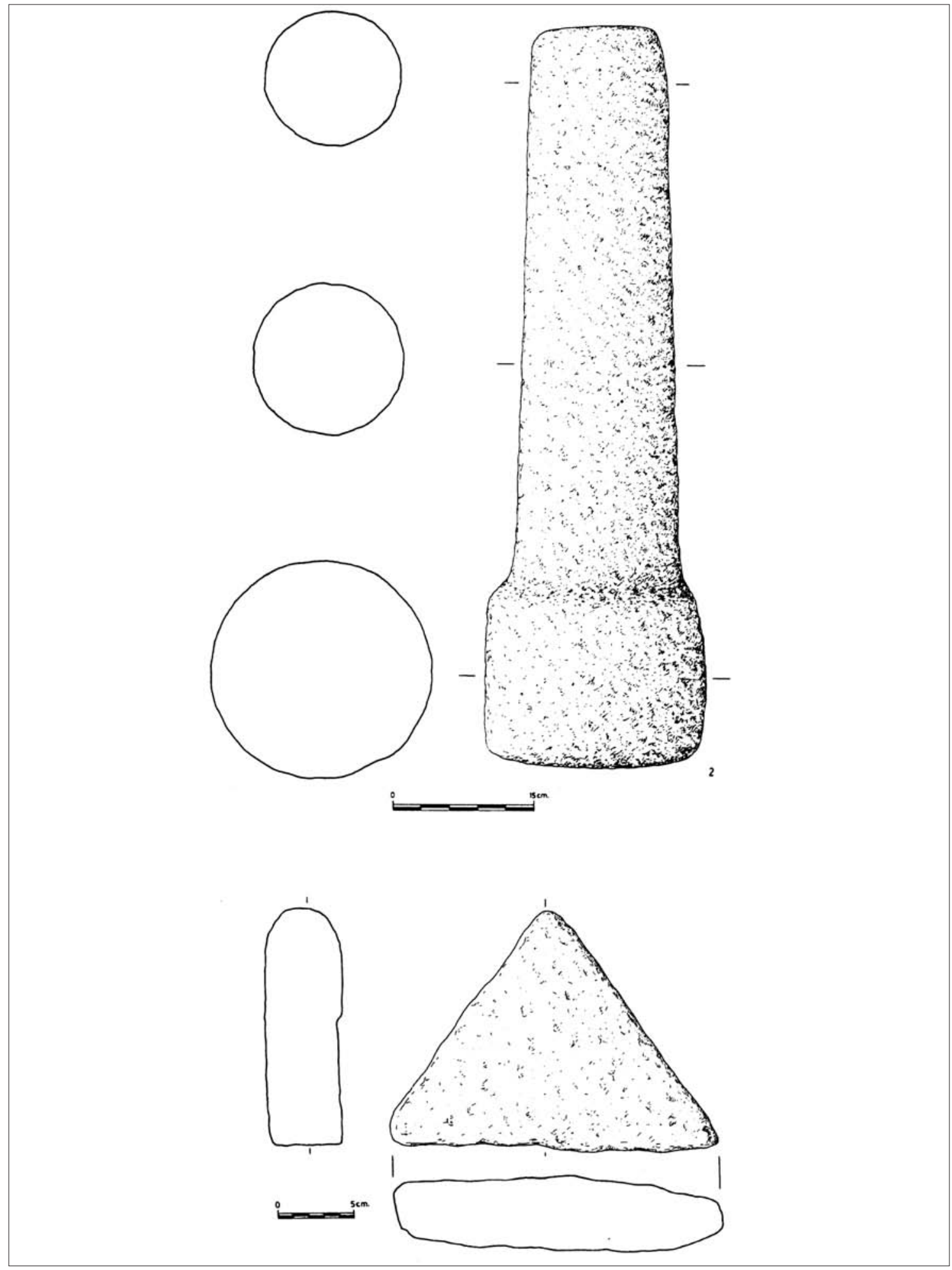

Figura 17. Piedras talladas encontradas, junto a otros objetos de probable carácter ritual en un pozo de Carmona (Sevilla). Compárese con la fig. 4, derecha (A partir de M. Belén, E. Conlin, R. Anglada 2001: Figs 6 y 7). 
buirse más a una columna votiva que a un edificio" ${ }^{47}$. En cualquier caso, estas estructuras deben ponerse en relación con pozos relativamente frecuentes en las necrópolis de Cádiz tanto en época púnica como republicana de varios metros de profundidad, colmatados en su mayoría de una sola vez. En ocasiones alcanzan el nivel freático ${ }^{48}$ y en ellos se depositan objetos empleados en actos litúrgicos asociados en general a los banquetes fúnebres como ánforas, lebrillos, morteros, vasos, jarras, cuencos, platos, urnas, lucernas, ungüentarios, monedas con la efigie de Jano, restos óseos de animales (bóvidos, ovicápridos, suidos, perros, peces y malacofauna), y, de forma excepcional, humanos, pesas de telar, anzuelos, agujas, terracotas femeninas y en ocasiones esculturas y piedras sueltas de origen no local (granito, gneis, pizarra), normalmente desbastadas y pulidas, que presentan formas cilíndricas o triangulares (Niveau de Villedary, 2001: 223; Id., 2006b: 43; Id., 2006a: 115, lám. II. Fig. 9.2, con bibliografía anterior).

\footnotetext{
47 Sin embargo, no se puede descartar por completo la ubicación de estos restos en el entorno de un espacio funerario al menos en alguna de sus fases, aunque desgraciadamente los datos de los que disponemos no son concluyentes. R. Corzo menciona la presencia de "un estrato de arena ennegrecida por una gran cantidad de cenizas y restos orgánicos, en el que se contiene la mayor parte del material arqueológico (...) un nivel discontinúo de enterramientos romanos de época imperial" y, en un estrato inferior, de restos de pequeñas "habitaciones" cuadrangulares de 3 por 3 metros de lado -a veces aisladas y a veces alineadas-, y de las que se habían conservado zócalos de guijarros (Corzo, 1991: 402), que podrían relacionarse con el tipo de acotados funerarios presentes en necrópolis como la propia Baelo Claudia, aunque R. Corzo les atribuye una fecha mucho más antigua. También P. Barbadillo Delgado menciona de forma imprecisa la presencia en el yacimiento de "casas" que contenían tinajas o ánforas rotas que guardaban "cenizas, huesos y restos de cerámica pequeña" (Barbadillo, 1951: 126) entre otros hallazgos, entre los que cabría destacar "otras muchas piedras en forma de cuadrante de círculo, de un radio de una cuarta aproximadamente, que parece servirían para la construcción de columnas mediante la superposición de ellas unidas por argamasa, habiéndose recogido asimismo algunas de estas piedras que por la mejor calidad de su materia, así como por su labrado se comprende eran las de remate para formar los fustes o capiteles" (Barbadillo, 1951: 129). Datos sobre la interpretación de este espacio como un temenos o espacio sagrado a cielo abierto con la bibliografía anterior en E. Ferrer Albelda (2002: 198-202).

48 Para A. M. Niveau (2006b: 43) "la función primaria de los pozos debía estar relacionada con la extracción de agua para su uso en la liturgia funeraria, como denota el hecho de que generalmente aparecen en las proximidades de otras estructuras hidráulicas como las piletas, incluso conectadas a éstas mediante canalillos. Una vez agotado el acuífero, las estructuras se reutilizaron, con una funcionalidad secundaria, como depósitos permanentes...".
}

A todo ello se añade ahora una pareja de cipos de piedra encontrada hace unos años en las cercanías de Montemolín (Marchena, Sevilla), que estaban acompañadas de dos terracotas estiliformes (de morfología similar a los exvotos de barro cocido del santuario del Carambolo ${ }^{49} \mathrm{y}$ que recuerdan a alguno de los cipos funerarios de Bolonia), tres urnas, un plato tapadera y siete cuencos de pequeño tamaño, que permiten fechar los materiales en el s. II a. C. Aunque se desconoce el contexto del hallazgo cabe suponer que pudieron haber sido depositadas en una favissa o un bothros, si bien no se puede descartar por completo que procedan de un contexto funerario (Bandera et al. 2004) (fig. 18). Finalmente, debe mencionarse una pieza excepcional - relacionada con el culto a los lares, si atendemos al epígrafe grabado en uno de los frentes- encontrada en la mina de San Ramón (Sierra de Portmán, Murcia). La parte superior de la losa presenta cuatro rebajes de forma circular (dos de $22 \mathrm{~cm}$ y dos de $8 \mathrm{~cm}$ de diámetro) que posiblemente sirvieron para acoger las figurillas a las que se ofrecía culto. El soporte mide 115 x 21 x $34 \mathrm{~cm}$ por lo que "no existe", según J. M. Abascal y S. F. Ramallo (1997: 470, n. 1140), "razón alguna para denominar el soporte como «tablero de altar», tal y como aparece en algunas ediciones". De hecho, el epígrafe se encontró asociado, según F. Fita ${ }^{50}$, a "clavos y una fíbula (rota) de bronce; una pesa de plomo piramidal, con orificio en la cúspide, que pesa unos 45 gramos, anillos de plomo, ...una lucerna de barro basto fracturada; un pedestal de estatua toscamente labrado; restos de urna cineraria... Cuando se hizo la excavación se mostró un pozo lleno de huesos humanos y cubierto por una plancha de cobre epigráfica, que ha desaparecido, muchas ánforas fracturadas... y muchísimas monedas de bronce, caracterizadas por el busto de Jano y la trirreme y ninguna de familia patricia o consular", así como a una "columnilla" cuya base presentaba un diámetro similar a los dos orificios de mayor tamaño ${ }^{51}$ (Beltrán, 1950: 257-259; Abascal, Ramallo, 1997: 469-472, $\mathrm{n}^{\circ}$

\footnotetext{
${ }^{49}$ Un comentario a la posible significación betílica de estas piezas y el contexto del hallazgo realizado por J. M. Carriazo en M. Belén y J. L. Escacena (2002: 169-170).

${ }^{50}$ F. Fita, "Excursión epigráfica por Villar del Rey, Alhambra, Venta de los Santos, Cartagena, Logroño y Orense", BRAH 42, 1903, p. 302 (citado en Abascal, Ramallo 1997: 469-470). La inscripción, que J. M. Abascal y S. F. Ramallo (1997: 470) han desarrollado de la siguiente manera: Sex(tus) $\cdot$ Numisius $\cdot$ l(ocum) $\cdot s($ anctum $) \cdot$ Larib [us] et $\cdot$ signa $\cdot$ et $\cdot$ aram $\cdot$ faciun [dam] coirauit $\cdot$ et $\cdot$ eisdem $\cdot$ dedic [auit], podría fecharse, atendiendo a distintos detalles epigráficos, en el último cuarto del s. I a. C.

51 Algunos autores han sugerido que la función de dos de estas oquedades era contener sendas columnas que servirían de soporte al entablamento y frontón de un larario (Beltrán, 1950: 257-258; Abascal, Ramallo, 1997: 469), a pesar de que aquéllas no están situadas respetando el eje de simetría de la pieza.
} 


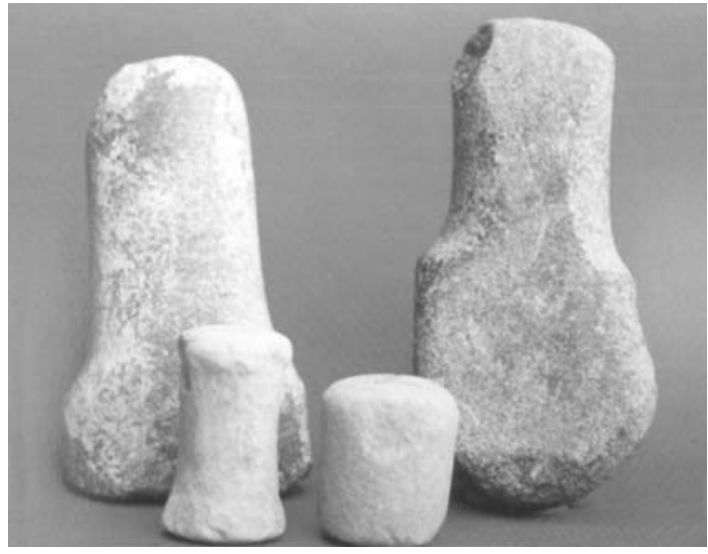

Figura 18. Cipos y terracotas votivas halladas en las cercanías de Montemolín (Marchena, Sevilla, según Bandera et al. 2004: fig. 5),

222, Lám. 193; González Ballesteros, 2003: 21). Es, sin duda, tentador relacionar estas oquedades con las que se observan en las lastras 'porta-cippi' encontradas en necrópolis etruscas y en la base de algunos lararios pompeyanos (Boyce, 1937: 22, 32, 61-62, n 9, 72, 73, 75, 249 , pl. 7.2, 23.1), un aspecto que merecería la pena investigar con más detalle (figs. 19, 20) ${ }^{52}$.

\section{CONCLUSIÓN}

En mi opinión, los cipos de Baelo Claudia, son el producto de una recreación muy particular de tradiciones locales, romanas y púnicas en la que muy posiblemente confluyeron el culto a los ancestros entendidos

\footnotetext{
${ }^{52}$ No es posible detenerse aquí en el análisis de otras piezas de morfología similar a algunos de los cipos de Bolonia encontradas en lugares dispersos de la Península Ibérica y especialmente en el Noroeste. El hallazgo reciente de varias de estas tallas dentro de castros y de tres ejemplares en contextos arqueológicos fiables demuestran la relación de algunas de ellas con contextos domésticos. La datación es problemática y es posible que deban situarse en los últimos siglos antes del cambio de era o incluso en el s. I d. C. Se han querido relacionar con el símbolo de la "cabeza cortada" que aparece sobre distintos soportes en el mundo "celta" y con la representación de númenes que protegerían espacios liminales como la entrada al poblado o los caminos (González Ruibal, 2006-2007: 444; 553-554). F. Calo (1994: 716-718, 720) compara específicamente las esculturas del NO con los cipos de Belo y los bustos de Tarento mencionados en este artículo y sugiere interpretar las "cabezas" del NO como imagines de los difuntos. Ver F. Calo (1994: 707-713) para una enumeración minuciosa de las teorías expuestas por distintos autores entorno a este problema hasta finales de los años ochenta del siglo XX. Agradezco a las Dras. C. Fernández-Ochoa y G. López Monteagudo haber llamado mi atención sobre este conjunto de piezas.
}

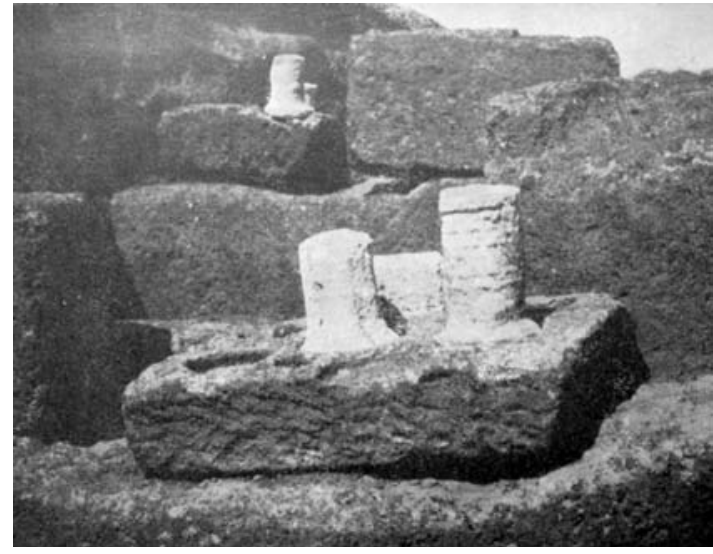

Figura 19. Cerveteri. Losas de piedra con oquedades que servían de soporte a los cipos funerarios de la necrópolis (según Mengarelli, 1915: fig. 9).

como entes más o menos indiferenciados y la idea de la piedra como casa del alma, a la que se ofrecen libaciones y a través de la cual se puede convocar a seres incorpóreos. Muy probablemente nos encontramos aquí ante la configuración de una serie de rituales que refleja el heterogéneo grupo de población que habitó un lugar abierto a muy distintas influencias. Las piedras talladas de Bolonia recuerdan -aunque no sean idénticas- a antiguos cipos funerarios etruscos que se mantuvieron en uso en su región de origen hasta finales de época republicana, y a determinados bustos funerarios característicos de la Campania, pero beben a la vez de tipos y modelos frecuentes en las necrópolis y tophets del mundo oriental -aunque no puedan asimilarse totalmente a ellos-, con los que comparten su carácter anepígrafo, en conexión con tradiciones locales muy vivas en la región, como demuestra el uso de una lengua neopúnica en la ciudad hasta momentos avanzados ${ }^{53}$.

En la península italiana encontramos representaciones tanto icónicas como anicónicas, que debieron estar relacionadas con el complejo proceso de creación de un 'doble' del difunto (entendido como individuo o como un nuevo integrante de una masa indiferenciada de ancestros que protegen a sus descendientes), que permitía llevar a cabo todo un conjunto de rituales junto a la tumba. Pero la idea de que la piedra puede ser 'habita-

53 A través de los hallazgos epigráficos del yacimiento puede entreverse también la mezcla de población de distintas procedencias a lo largo de la historia, así como el paso por la ciudad de individuos con nombres de origen itálico, como el caso de los Pupii, nombre característico de la Italia etrusca y del que apenas se conoce otro ejemplo en Cartagena, pero también africanos (Honoratus, Novata, Optata, Rogata, Novellus, Saturninus), púnicos (nombre acabado en "rbal") y orientales (Eleuthera, Eurmenes, Phiale, Phoebas, Progne, Pyra, Suriacus) (Sillières, 1997: 35). 


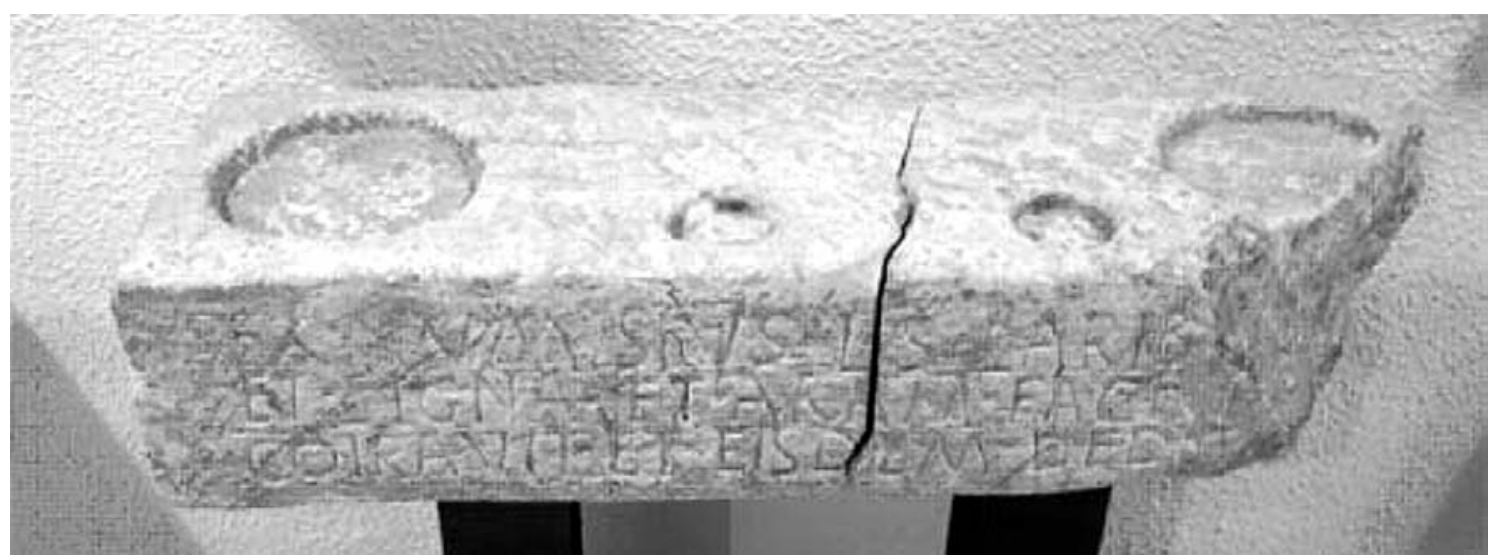

Figura 20. Losa con epígrafe alusivo a los lares hallada en la mina de San Ramón (Sierra de Portmán, Murcia, Museo Arqueológico Municipal de Cartagena, $\mathrm{n}^{\circ}$ inv. 671). Los agujeros circulares (similares a los que presentan las lastras 'portacipos' de algunas necrópolis etruscas) han sido también documentados en lararios de Pompeya y se cree que en ellos se depositarían las figurillas a las que se ofrecía culto (tomada de González Ballesteros, 2003: fig. 5).

da' por un númen -o por una divinidad- no es extraña al mundo oriental, hasta el punto de que la palabra con la que se alude al alma vegetativa en el mundo fenicio (néphesh) llega a utilizarse en la epigrafía funeraria para referirse también al monumento funerario (Sader, 2005: 21). En regiones bajo la órbita púnica se puede rastrear, en distintos momentos, la tendencia a superponer elementos de carácter antropomorfo a determinados betilos, o a grabar someros trazos que evocan el rostro humano en cipos que debían estar situados sobre el sepulcro, como demuestra el pequeño "catálogo" de piezas procedentes de distintos yacimientos que ha sido comentado. Las similitudes entre los cipos asociados a las cupae de Bolonia en momentos avanzados del Imperio y las piedras talladas presentes en tumbas del mismo tipo de la necrópolis de la puerta Cesarea Tipasa, demuestran que este fenómeno de interacción y reelaboración de distintas tradiciones funerarias se mantuvo vivo a lo largo de varias generaciones en el asentamiento gaditano. Los cipos funerarios de Belo pueden ser entendidos únicamente dentro de un contexto mediterráneo, que, simultáneamente, realza su especificidad.

Este conjunto de esculturas es, hasta el momento, un caso excepcional en la Bética, si exceptuamos piezas aisladas como las encontradas en Carmona y Montemolín (Belén, Lineros, 2001; Belén, Conlin, Anglada 2001; Bandera et al. 2004). En Baelo Claudia, sin embargo, se hallaron más de un centenar de estas tallas realizadas en época imperial, que adoptan, de forma consciente, un aspecto tradicional y arcaizante, tanto si consideramos la influencia de modelos norteafricanos, como si tenemos en mente la conexión con piezas etruscas que fueron desapareciendo paulatinamente de las necrópolis de la península italiana a finales de la república. Los cipos de Belo documentan, a la vez, la llegada y reinterpretación por parte de la población local de prácticas rituales asociadas a clases más o menos populares en sus lugares de origen. De esta forma, es posible complementar una percepción un tanto parcial del proceso de colonización romano y su reflejo en el ámbito de las necrópolis, basada, casi exclusivamente, con frecuencia, en el estudio de la adaptación de determinados tipos monumentales de la arquitectura funeraria de las elites romanas en la península ibérica.

Las piezas de Bolonia pueden considerarse un ejemplo privilegiado para estudiar el denominado proceso de 'romanización', o la creación de una sociedad especialmente híbrida a partir del asentamiento de gentes procedentes de la península itálica, y su reflejo en los contextos funerarios directamente relacionados con la recreación de la identidad individual y colectiva que adopta formas características en cada núcleo urbano (Bendala, 2002; Jiménez Díez, 2002). En este contexto, como ha señalado M. Bendala (2005: 27) "cada ciudad se configura como un conjunto con entidad propia, que no sólo puede generar un paisaje específico, sino que parece necesitarlo como respuesta a la misma pulsión interna a recordar la biografía colectiva que está en el origen de la Historia, la capacidad de generar un ecosistema a la medida de sus necesidades específicas".

La manera en que se rinde culto a los antepasados es un elemento esencial en la reelaboración continua de la imagen que se proyecta sobre el pasado de la comunidad ciudadana. Los rituales asociados a los muertos permiten escenificar no sólo quién se ha sido, sino también quién se es. La memoria colectiva se va estructurando de forma paulatina mediante una repetición idealizada o de tipo platónico de distintas narrativas sobre los orígenes del grupo, a través de las cuales la identidad se va construyendo en torno a similitudes con el pasado. En este tipo de escenarios, la propia identidad, la 'verdad' y la 
'autenticidad' implican una vuelta continua a una pretendida forma 'original' de ser (Rowlands, 1988: 4445). Sin embargo, como hemos visto en el empleo de elementos tradicionales como los cipos de Bolonia, ese mundo de simulacra nunca reproduce una copia exacta del pasado, sino más bien una reformulación del 'eco' de sus imágenes. Pero estas imagines no son ya, inevitablemente, y por definición, ni 'romanas' ni 'nativas' sino hybridae, fruto de la unión durante generaciones de población local con los inmigrantes de la península italiana y de la multiplicidad de discursos sobre qué significaba 'ser romano' que surgieron como consecuencia.

Esta forma de acercarse al problema permite plantear una interpretación alternativa sobre todas aquellas manifestaciones que no se ajustan al 'modelo' de mundo romano que hemos establecido, especialmente si tenemos en cuenta que lo que se suele denominar "pervivencias" ${ }^{54}$ son elementos que a menudo no presentan una línea de estricta continuidad con el pasado prerromano, sino que en muchas ocasiones tanto objetos como instituciones de carácter tradicional se reformulan y adoptan nuevos significados para adaptarse a un nuevo contexto (Van Dommelen, 2006: 115; Jiménez Díez, e.p.b).

Las dificultades que encontramos, por ejemplo, para encuadrar dentro de la categoría de 'púnico' o 'romano' a poblaciones asentadas desde época orientalizante en la península ibérica, que de alguna manera podrían ser ya consideradas nativas a principios del s. II a. C. desaparecerían si abandonásemos la necesidad de traducir la realidad del mundo antiguo a oposiciones binarias de carácter colonial, que en el fondo son una transposición de la oposición entre los conceptos de yo/el otro transmitida por las fuentes grecolatinas que arqueólogos e historiadores nos hemos encargado de perpetuar (Rowlands, 1998: 328, Van Dommelen 2001a: 72; Id., 2001b: 124; Jiménez Díez, e.p.a). En ese "tercer espacio" que ya no es netamente 'romano' o 'indígena' donde se reformula, se traduce y se lee de nuevo los signos culturales se articula el hibridismo que permite superar la noción de 'romanización' como el resultado de la oposición de un conjunto de culturas (Bhabha, 1994: 39; Gosden, 2001: 247).

Como en otros contextos coloniales, nos encontramos con un complejo panorama que no se ajusta bien ni a un modelo de una sociedad multiétnica donde se ha producido un fenómeno de asimilación y fusión completa de distintos grupos en contacto, ni a un patrón de estricta diferenciación de conjuntos étnicos a través de la cultura material. Nos enfrentamos más bien a la superposición de distintas formas de expresar 'quién se es' mediante el consumo de objetos: discursos en los que aspectos relacionados con la identidad como el estatus, el género o la

${ }^{54}$ Un análisis crítico sobre el concepto de "pervivencia" se puede encontrar en M. Bendala (1987: 570; 2002: 140). ciudad de origen se entrecruzan y confunden con supuestas distinciones entre 'colonizador' y 'nativo' (Rowlands, 1999: 340; Tronchetti, Van Dommelen, 2005: 193). Si aceptamos que la sociedad se encuentra sometida a cambios continuos y que la identidad se forja a través de la continua reformulación de los sentimientos de auto-adscripción a un grupo, no sería tan necesario tratar de explicar el cambio -la 'romanización'- sino lo que 'aparentemente' permanece (Rowlands, 1982: 172), la continua recreación del pasado en el presente que tanta relación tiene en las necrópolis con el mundo de los ancestros.

Los cipos funerarios de Baelo se sitúan frente a los monumentos o sobre las tumbas, mirando al mar, hacia las costas africanas que se vislumbran desde la playa los días claros, semienterrados, conectando de alguna manera al individuo o los individuos que descansan bajo tierra y a los familiares que realizan un conjunto de rituales funerarios a lo largo del año. En este sentido, los 'muñecos' pudieron cumplir metafóricamente la función de los conductos de libación, tan frecuentes en las necrópolis norteafricanas durante época imperial, señalando la frontera y, simultáneamente, poniendo en comunicación dos espacios limítrofes desde un punto de vista ritual: la tumba -una especie de mundus o boca del mundo inferior consagrada a los Manes (Rykwert, 1976: 54, 149)- y el mundo terreno. Junto a ellos -o sobre ellos, si hacemos caso a G. Bonsor-, se lleva a cabo el ritual de la profusio, se rompen los vasos utilizados en el banquete y, quizás, se invocan y "atrapan" momentáneamente, las almas de los ausentes cuando son requeridas para el culto a los ancestros. Los cipos pudieron ser utilizados durante festividades dedicadas a los difuntos como receptores de los sacrificios realizados a los muertos, entendidos como una comunidad de carácter genérico o indiferenciado, o como mensajero para un familiar concreto que hubiese fallecido. Los 'muñecos' serían, por tanto, un ente concreto frente al que invocar almas concretas -en este sentido un doble, un colossos-, pero a la vez un representante de los muertos o antepasados como colectivo, igual que los Manes o los Lares, encargados de vigilar el bienestar de la familia en este caso desde el más allá. Por eso los cipos de Belo no son la copia exacta de unas facciones determinadas, por eso pueden presentar un rostro estereotipado o ser completamente anicónicos, esa es la razón por la que pueden aparecer en grupo -como en los lararios- sin que exista necesariamente una correspondencia con el número de enterramientos a los que se superponen y de ahí que exhiban un aspecto decididamente arcaizante. No son retratos, porque no es necesario que lo sean. Los 'muñecos' pudieron cumplir la función de recibir al difunto, como los propios Manes, dioses inferorum al igual que los Lares, los padres de los padres que nos precedieron, como garantes del bienestar y la continuidad de la familia -de la fertilidad, al fin y al cabo-, en su faceta de dioses del inframundo. 


\section{BIBLIOGRAFÍA}

ABASCAL, J. M.; RAMALLO, S. F. (1997): La ciudad de Carthago Nova: la documentación epigráfica, Murcia.

ALFARO, C.; ARÉVALO, A.; CAMPO, M.; CHAVES, F.; DOMÍNGUEZ, A.; RIPOLLÉS, P. P. (1997): Historia monetaria de la Hispania Antigua, Madrid.

ÁLVAREZ ROJAS, A. (2002): "Paisaje y patrimonio. El caso de Baelo Claudia", Mérida. Ciudad y Patrimonio $6,11-20$.

ANTONELLI, U. (1927): “Tivoli. Fossa di età romana, republicana e con materiali arcaici, scoperta in contrada «Acquoria»" Notizie degli scavi di antichità $\mathrm{V}$ (52), 215-249.

ARÉVALO, A; BERNAL, D. (eds.) (2007): Las cetariae de Baelo Claudia. Avance de las investigaciones arqueológicas en el barrio meridional (2000-2004), Cádiz.

BANDERA, M. L. de la; FERRER ALBELDA, E.; GARCÍA FERNÁNDEZ, F. J.; CAMACHO MORENO, M. (2004): "Nuevas evidencias de cultos betílicos en Turdetania”, Huelva Arqueológica 20, 241-255.

BARBADILLO, P. (1951): Alrededor de Tartessos. Los descubrimientos de la Algaida, Sanlúcar de Barrameda.

BARTOLONI, P. (1986): Le stele di Sulcis, Roma.

BELÉN, M. (1992-1993): "Religiosidad funeraria en la necrópolis de Cádiz”, Tabona, VIII (2), 351-371.

- (1994): "Aspectos religiosos de la colonización fenicio-púnica en la Península Ibérica. Las estelas de Villaricos (Almería)", Spal 3, 257-279.

BELÉN, M.; CONLIN, E.; ANGLADA, R. (2001): "Cultos betílicos en Carmona romana" Arys 4, Antigüedad: religiones y sociedades, 141-164.

BELÉN, M.; LINEROS, R. (2001): “15 años de Arqueología en Carmona”, A. Caballos Rufino (ed.), Actas del II Congreso de Historia de Carmona (Carmona, 29 de septiembre-2 de octubre de 1999), Carmona, 109-133.

BELÉN, M.; ESCACENA, J. L. (2002): "La imagen de la divinidad en el mundo tartésico", E. Ferrer Albelda (ed.), Ex Oriente Lux: las religiones orientales antiguas en la Península Ibérica. Spal. Monografías II, Sevilla, 157-184.

BELTRÁN, A. (1950): "Las lápidas latinas religiosas y conmemorativas de Cartagena", AEspA 13, 255-278.

BENDALA GALÁN, M. (1976): La necrópolis romana de Carmona (Sevilla), Sevilla.

- (1987): "La cultura en la Hispania Romano-Republicana. Cuestiones generales", en Historia General de España y América, Vol. 1-2, Madrid, 569-592.

- (1989-1990): “Capitolia Hispaniarum”, Anas 2-3, 11-36.
- (1991): "Incinérations et inhumations dans l'occident romain aux trois premiers siècles de notre ère: le sud de l'Espagne", Incinérations et inhumations dans l'occident romain. IVe Congrès Archéologique de Gaule Méridionale, Toulouse, 77-90.

- (1995): "Necrópolis y ritual funerario en la Hispania altoimperial", R. Fábregas, F. Pérez, C. Fernández (eds.), Arqueoloxía da Morte na Península Ibérica desde as Orixes ata o Medievo, Xinzo de Limia, 279-290.

- (2002): "Perduraciones y romanización en Hispania a la luz de la arqueología funeraria: notas para una discusión", AEspA 75, 137-158.

- (2005): "Urbanismo y romanización en el territorio andaluz: aportaciones a un debate en curso", Mainake XXVII, 9-32.

- (e.p.): "Continuidad y renovación en los centros sacros de las ciudades hispanorromanas", IV Simposio Internacional de Arqueología de Mérida: Santuarios, oppida y ciudades: Arquitectura sacra en el origen y desarrollo urbano del Mediterraneo occidental, Instituto de Arqueología de Mérida (CSIC), Mérida, 2005.

BENICHOU-SAFAR, H. (1982): Les tombes puniques de Carthage. Topographie, structures, inscriptions et rites funéraires, Paris.

BETTINI, M. (1988 [1991]): Anthropology and Roman Culture: Kinship, Time, Images of the Soul, Baltimore. [Primera edición en italiano: Antropologia e cultura romana: Parentela, tempo, immagini dell'anima, Roma]

- (1992): "Culto degli antenati e culto dei morti", S. Settis (ed.), Civiltà dei romani. Vol. III. Il rito e la vita privata, Milano, 260-264.

BHABHA, H. K. (1994 [2002]): The location of culture, London, New York.

BISI, A. M. (1967): Le stele puniche, Studi Semitici 27, Roma.

- (1970): "Prolegomena per una storia dell'architettura funeraria punica in Sicilia. I. Le necropoli di Erice e di Lilibeo", Kokalos XVI, 209-222.

- (1971): "Lilibeo (Marsala). Nuovi scavi nella necropoli punica (1969-1970)", Atti della Accademia Nazionale dei Lincei. Notizie degli Scavi di Antichità, Serie Ottava, vol. XXV, 662-762.

BIZZARRI, M. (1962): "La necropoli di Crocefisso del Tufo in Orvieto", Studi Etruschi XXX, 1-151.

BLUMHOFER, M. (1993): Etruskische Cippi. Untersuchungen am Beispiel von Cerveteri, Köln.

BONAMICI, M. (1991): "Nuovi monumento di marmo dall'Etruria settentrionale", Archeologia Classica vol. XLIII.2, 795-817.

BONDI, S. F. (1972): Le stele di Monte Sirai, Roma.

BONNEVILLE, J. N.; FINCKER, M.; SILLIÈRES, P.; DARDAINE, S. ; LABARTHE, J. -M. (2000): Belo VII. Le capitole, Madrid. 
BOST, J. P.; CHAVES, F.; DEPEYROT, G.; HIERNARD, J.; RICHARD; J. C. (1987): Belo IV. Les monnaies, Publications de la Casa de Velázquez, Série Archéologie, VI, Madrid.

BOURGEOIS, A.; DEL AMO, M. (1970): "Chronique. La quatrième campagne de fouilles à Belo-Bolonia (province de Cadix) en 1969", Mélanges de la Casa de Velázquez VI, 439-456.

BOYCE, G. K. (1937): Corpus of the lararia of Pompeii (Memoirs of the American Academy in Rome, Vol. XIV), Roma.

CALO, F. (1994): A plástica da Cultura Castrexa Galego-Portuguesa, A Coruña.

COLONNA DI PAOLO, E.; COLONNA, G. (1970): Le necropoli rupestri dell'Etruria meridionale. Castel D'Asso, Roma.

COMELLA, A. (1978): Il materiale votivo tardo di Gravisca, Roma.

CORZO, R. (1991): "Piezas etruscas del santuario de la Algaida (Sanlúcar de Barrameda, Cádiz)”, J. Remesal, O. Musso (eds.), La presencia de material etrusco en la Península Ibérica, Barcelona, 399-411.

CRISTOFANI, M. (ed.) (1973): "Rivista di epigrafia etrusca", Studi Etruschi XLI, 269-362.

CUNLIFFE, B; FERNÁNDEZ CASTRO, M. C. (1999): The Guadajoz Project. Andalucía in the first millennium B. C. Volume I: Torreparedones and its hinterland, Oxford.

D’AMBROSIO, A.; DE CARO, S.; VLAD BORELLI, L. (1983): Un impegno per Pompei, Milano.

D’AMBROSIO, A.; DE CARO, S. (1987): "La necropoli de Porta Nocera. Campagna di scavo 1983", H. von Hesberg, P. Zanker (eds.), Römische Gräberstraßen: Selbstdarstellung, Status, Standard, München, 199-228.

DARDAINE, S. ; BONNEVILLE, J. -N. (1980) : "La campagne de fouilles d'octobre 1979 à Belo", Mélanges de la Casa de Velázquez XVI, 375-419.

DE'SPAGNOLIS, M. (2001): "Costumi funerari romani nella necropoli monumentale romana di Pizzione a Nocera Superiore", M. Heinzelmann et al., eds., Römischer Bestattungsbrauch und Beigabensitten, Norditalien und den Nordwestprovinzen von der später Republik bis in die Kaiserzeit, Internationales Kolloquium, Rom 1.-3. April 1998, Wiesbaden, 169-177.

DIDIERJEAN, F.; NEY, C.; PAILLET, J. -L. (1986): Belo III. Le Macellum, Madrid.

DOMERGUE, C. (1973): Belo I. La stratigraphie, Paris.

FAMÀ, M. L.; TUSA, V. (2000): Le stele del Meilichios di Selinunte, Padova.

FERRER ALBELDA, E. (2002): “Topografía sagrada del Extremo Occidente: santuarios, templos y lugares de culto de la Iberia púnica", E. Ferrer Albelda (ed.), Ex Oriente Lux: las religiones orientales anti- guas en la Península Ibérica. Spal. Monografías II, Sevilla, 185-217.

FÉVRIER, P. A. (1970): "La nécropole orientale de Tiddis", Bulletin d'Archéologie Algérienne, IV, 41-100.

FÉVRIER, P. A.; GASPARY, A. (1966-1967): "La nécropole orientale de Séti", Bulletin d'Archéologie Algérienne II, 11-93.

FLOWER, H. (1996): Ancestor masks and aristocratic power in Roman culture, Oxford.

FOSS, P. W. (1997): "Watchful Lares: Roman household organization and the rituals of cooking and eating", R. Laurence; A. Wallance-Hadrill (eds.), Domestic Space in the Roman World: Pompeii and Beyond, JRA Supplementary Series 22, 197-218.

FRÖHLICH, T. (1991): Lararien und Fassadenbilder in den Vesuvstädten. Untersuchungen zur „Volkstümlichen " pompejanischen Malerei, Mainz.

FURGÚS, J. (1907): "Les ruines de Bélon, province de Cadix (Espagne)", Annales de la Société d'archéologie de Bruxelles, t. XXI, 1907, p. 149-160.

- (1908): "Antigüedades romanas en la costa gaditana”, Razón y Fe, XXI, 2, 205-217.

GARCÍA Y BELLIDO, A. (1955 [1979]): Arte romano, Madrid.

GARCÍA Y BELLIDO, A.; NONY, D. (1969): "Les fouilles de la Casa de Velázquez à Belo-Bolonia (Cádiz) en 1968", Mélanges de la Casa de Velázquez. $\mathrm{V}, 465-478$.

GARCÍA-BELLIDO, M. P. (1985-86): "Leyendas e imágenes púnicas en las monedas libio-fenicias", Veleia 2-3. Studia Paleohispanica. Actas del IV Coloquio sobre lenguas y culturas paleohispánicas. Vitoria-Gasteiz, 6 - 10 de mayo de 1985, 499-519. - (1993): "Las cecas libio-fenicias", Numismática hispano-púnica. VII Jornadas de Arqueología feniciopúnica. Ibiza, 97-146.

- (2001): "Recensiones: P. Sillières, Baelo Claudia. Una ciudad romana de la Bética y J. -N. Bonneville et al., Belo VII. Le Capitole", AEspA 74, 325-327.

GARCÍA-BELLIDO, M. P.; BLÁZQUEZ, C. (2001): Diccionario de cecas y pueblos hispánicos: con una introducción a la numismática antigua de la Península Ibérica, Madrid.

GATTI LO GUZZO, L. (1978): Il deposito votivo dall'Esquilino detto di Minerva Medica, Firenze.

GLARE, P. G. W. (ed.) (1968a [1992]): s. v. "Cip(p)us", Oxford Latin Dictionary, Oxford, 316.

- (1968b [1992]): s. v. "Imago", Oxford Latin Dictionary, Oxford, 831.

GONZÁLEZ BALLESTEROS, J. A. (2003): "Una aproximación a la arquitectura religiosa doméstica de época romana", Revista ArqueoMurcia nº1, 1-22 (artículo en línea: http://www.arqueomurcia.com/revista/, ISSN 1696-974X). 
GONZÁLEZ RUIBAL, A. (2006-2007): Galaicos. Poder y comunidad en el Noroeste de la Península Ibérica (1200 a. C. - 50 d. C.), Brigantium 18-19, A Coruña.

GOSDEN, C. (2001): "Postcolonial archaeology: issues of culture, identity and knowledge", I. Hodder (ed.), Archaeological Theory Today, Cambridge, 241-261.

GUADÁN, A. M. (1969): Numismática ibérica e iberoromana, Madrid.

HARMON, D. P. (1978): "The family festivals of Rome", Aufstieg und Niedergang der römischen Welt 16.2, 1592-1603.

JIMÉNEZ DÍEZ, A. (2002): "Necrópolis de época republicana en el mediodía peninsular: «romanización» y sentimientos de identidad étnica”, D. Vaquerizo (ed.), Espacio y usos funerarios en el occidente romano, Córdoba, 217-231.

- (e.p.a): Imagines Hibridae. Una aproximación postcolonialista al estudio de las necrópolis de la Bética y al debate sobre la 'romanización', Anejos del Archivo Español de Arqueología, Madrid.

- (e.p.b): "A critical approach to the concept of resistance: new 'traditional' rituals and objects in funerary contexts of Roman Baetica", Proceedings of the Seventeenth Theoretical Roman Archaeology Conference, Oxford.

KLEINER, D. E. E. (1977): Roman Group Portraiture. The Funerary Reliefs of the Late Republic and Early Empire, New York, London.

KOCKEL, V. (1987): "Im Tode gleich? Die sullanischen Kolonisten und ihr kulturelles Gewicht in Pompeji am Beispiel der Nekropolen", H. von Hesberg, P. Zanker (eds.), Römische Gräberstraßen: Selbstdarstellung, Status, Standard, München, 183-198.

LANCEL, S. (1970): “Tipasitania IV, La nécropole romaine occidentale de la porte de Césarée: rapport préliminaire", Bulletin d'Archéologie Algérienne 4, 149-266.

LIPINSKI, E. (dir.) (1992): Dictionnaire de la civilisation phénicienne et punique, Brepols.

MAIURI, A. (1932): La casa del Menandro e il suo tesoro di Argentaria, Roma.

MENGARELLI, R. (1915): “Cerveteri. Nuovi esplorazioni nella necropoli di Caere. Tombe di età posteriore al V sec. av. Cr., e cippi sepolcrali", Notizie degli Scavi di Antichità XII, 347-386.

MERGELINA, C. (1927): La necrópoli Hispano-Romana de Baelo, «Actas y Memorias» de la Sociedad Española de Antropología, Etnografía y Prehistoria, tomo VI, 1927, Mem. LIV, Madrid.

MOSCATI, S. (1995): Luci sul Mediterraneo: dai manoscritti del Mar Morto ai Cartaginesi in Italia, tre millenni di vicende storiche, di concezioni religiose, di creazioni artistiche alla luce dell'archeologia, Roma.

MOSCATI, S.; ALBERTI, M. L. (1981): Scavi a Mozia. Le stele, Serie Archeologica, 23, Roma.
MOSCATI, S.; UBERTI, M. L. (1985): Scavi al tofet di Tharros. I. Monumento lapidei, Collezione di Studi Fenici, 21, Roma.

MOSCATI, S.; LO SCHIAVO, F.; PITZALIS, G.; UBERTI, M. L. (1992): Le stele a specchio. Artigianato popolare nel Sassarese, Roma.

NEY, C.; PAILLET, J. -L. (2006): "La basilique de BaeloClaudia: Etude architecturale", I Jornadas Internacionales de Baelo Claudia: Balance y perspectiva (19662004) (Octubre, 2004), Sevilla, 93-136.

NIVEAU DE VILLEDARY, A. M. (2001): "Pozos púnicos en la necrópolis de Cádiz: evidencias de prácticas rituales funerarias", Rivista di Studi Fenici XXIX, 2, 183-230.

- (2006a): "Estudio de materiales procedentes de los pozos rituales y fosas de la necrópolis púnica de Cádiz (2002-2003)", Anuario de Arqueología Andaluza 2003, Sevilla, 102-118.

- (2006b): "Banquetes rituales en la necrópolis púnica de Gadir", Gerion 24.1, 35-64.

ORR, D. G. (1978): "Roman domestic religion: the evidence of the household shrines", Aufstieg und Niedergang der Römischen Welt 16.2, 1557-1591.

- (1988): "Learning from lararia: notes on the household shrines of Pompeii", R. I. Curtius (ed.), Studia Pompeiana et Classica: in honour of Wilhelmina F. Jashemski, New York, 293-299.

PALlOTTINO, M. (1937): Tarquinia, Monumenti AntAccNazLincei XV, Roma.

PARIBENE, E. (ed.) (1999): Acheronticae Columellae. Cippi funerari della Versilia Etrusca, Pietrasanta.

PARIS, P. (1917): "Promenade archéologique a Bolonia (Province de Cadix)", Bulletin Hispanique XIX, $\mathrm{n}^{\circ}$ 4, 221-242.

PARIS, P.; BONSOR, G.; LAUMONIER, A.; RICARD, R.; MERGELINA, C. (1923): Fouilles de Belo (Bolonia, Province de Cadix) (1917-1921). Tome I. La ville et ses dépendances, Bordeaux - Paris.

PARIS, P. ; BONSOR, G. ; LAUMONIER, A. ; RICARD, R. ; MERGELINA, C. (1926): Fouilles de Belo (Bolonia, Province de Cadix) (1917-1921). Tome II. La Nécropole, Bordeaux - Paris.

PENSABENE, P. (1975): "Cippi funerari di Taranto", $\operatorname{MDAI}(R)$ 82, 263-297.

- (1977): "Cippi, busti, ritratti. Nota in margine a: M. F. Kilmer, The shoulder bust in Sicily and central Italy, Götenborg 1977”, Archeologia Classica XXIX-2, 425-435.

PENSABENE, P.; RIZZO, M. A.; ROGHI, M.; TALAMO, E. (1980): Terracotte votive dal Tevere, Roma.

PERA, R. (1993): "La moneta antica come talismano", Rivista Italiana di numismatica e scienze affini 95, 347-361.

PICARD, CH. (1943): "Sanctuaires et symboles de Zeus Meilichios”, Revue de l'histoire des Religions, 97-127. 
- (1967): "Sacra punica. Étude sur les masques et rasoirs de Carthage", Karthago XIII.

PICARD, G. (1962): I Cartaginese al tempo de Annibale, Milano.

PONSICH, M. (1966): "Cippe funéraire à Volubilis", Bulletin d'Archéologie Marocaine 6, 470-472.

RAMOS CRESPO, J. M. (1988): “«Pilae», «efigies» y «maniae» en las Compitalia romanas", Helmantica tomo 39, núm. 118-119, 207-222.

REMESAL RODRÍGUEZ, J. (1979): La necrópolis sureste de Belo, E.A.E. 104, Madrid.

RODRÍGUEZ OLIVA, P. (1994): "Materiales arqueológicos y epigráficos para el estudio de los cultos domésticos en la España romana", Actas del VIII Congreso Español de Estudios Clásicos (Madrid, 2328 de septiembre de 1991), Vol. III, Madrid, 5-40.

- (2002): "Talleres locales de urnas cinerarias y de sarcófagos en la prouincia Hispania Ulterior Baetica", Espacios y usos funerarios en el Occidente Romano, D. Vaquerizo (ed.), Córdoba, 259-311.

ROSI, G. (1927): "Sepulchral architecture as illustrated by the rock facades of central Etruria. Part II", JRS 17, 59-96.

ROUILLARD, P.; REMESAL, J.; SILLIÈRES, P. (1979): "Novena campaña de excavaciones en Belo, 1974 (Bolonia, Cádiz)", Noticiario Arqueológico Hispánico. Arqueología 6, 309-326.

ROWLANDS, M. (1982): "Processual Archaeology as Historical Social Science", C. Renfrew, M. Rowlands, B. Abbot Segraves, eds., Theory and Explanation in Archaeology, New York, London, 155-174.

- (1988): "Repetition and exteriorisation in narratives of historical origins", Critique of Anthropology 8. n.2, 43-62.

- (1998): "The Archaeology of Colonialism", K. Kristiansen y M. Rowlands eds., Social transformation in Archaeology. Global and local perspectives, London, New York, 327 - 333.

- (1999): "Black identity and sense of past in Brazilian national culture", P. Funari, M. Hall, S. Jones (eds.), Historical Archaeology, London, 328-344.

RYKWERT, J. (1976 [1985]): La idea de ciudad. Antropología de la forma urbana en el mundo antiguo, Madrid.

SADER, H. (2005): Iron Age funerary stelae from Lebanon, Barcelona.

SAGLIO, E. (1887): s.v. "Cippus", C. Daremberg, E. Saglio, Dictionnaire des Antiquités Grecques et Romaines, vol. I.2, Paris, 149.

SECO SERRA, I. (1999): "El betilo estiliforme de Torreparedones", Spal 8, 135 - 158.

- (2003): Piedras con alma: el betilismo en el mundo antiguo y sus manifestaciones en la Península Ibérica, Tesis Doctoral inédita, Universidad Autónoma de Madrid, Madrid.
SILLIÈRES, P. (1997): Baelo Claudia, una ciudad romana de la Bética. Madrid.

- (2006): "Investigaciones arqueológicas en Baelo: balance, interpretación y perspectivas", I Jornadas Internacionales de Baelo Claudia: Balance y perspectiva (1966-2004) (Octubre, 2004), Sevilla, 37-60.

SOLÁ-SOLÈ, J. M. (1980): El alfabeto monetario de las cecas "libio-fenicias", Barcelona.

STEINGRÄBER, S. (1991): "Etruskische Monumental cippi”, Archeologia Classica vol. XLIII.2, 1079-1102. - (2002): "Ahnenkult und bildliche Darstellungen von Ahnen in etruskischen und unteritalischen Grabgemälden aus vorrömischer Zeit”, J. Munk Højte (ed.), Images of Ancestors, Aahurs, 127-158.

TORE, G. (1975): "Su alcune stele funerarie sarde di età punico-romana", Latomus 34, 293-318.

TRONCHETTI, C.; VAN DOMMELEN, P. (2005): "Entangled objects and hybrid practices: colonial contacts and elite connections at Monte Prama, Sardinia", Journal of Mediterranean Archaeology 18.2, 183-209.

VAGNETTI, L. (1971): Il deposito votivo di Campetti a Veio: materiali degli scavi 1937-1938, Fireze.

VAN DOMMELEN, P. (2001a): "Cultural imaginings. Punic tradition and local identity in Roman Republican Sardinia", S. Keay, N. Terrenato (eds.), Italy and the West. Comparative Issues in Romanization, Oxford, 68-84.

- (2001b): "Ambiguous Matters: Colonialism and Local Identities in Punic Sardinia", C. L. Lyons, J. K. Papadopoulos (eds.), The Archaeology of Colonialism, Los Angeles, 121-147.

- (2006): "Colonial matters. Material culture and Postcolonial Theory in colonial situations", C. Tilley, W. Keane; S. Kuechler, M. Rowlands, P. Spyer (eds.), Handbook of material culture, London, 104-124.

VAQUERIZO, D. (2002): "Recintos y acotados funerarios en Colonia Patricia Corduba", Madrider Mitteilungen 43, 168-206.

- (2006): "Sobre la tradición púnica, o los influjos norteafricanos, en algunas manifestaciones arqueológicas del mundo funerario hispano-bético de época pleno-imperial. Una revisión crítica", D. Vaquerizo, J. F. Murillo (eds.), El concepto de lo provincial en el mundo antiguo, Homenaje a la Prof. Pilar León, Córdoba, Vol. II, 317-363.

VILLARONGA, L. (1979): Numismática antigua de Hispania, Barcelona.

- (1994): Corpus Nummum Hispaniae ante Augusti Aetatem, Madrid.

WALLACE-HADRIL, A. (1988): "The social structure of the Roman house", Papers of the British School at Rome 56, 43-97.

Recibido el 16-11-06 Corregido el 12-03-07 